\title{
Decadência longe do poder: refundação e crise do PFL
}

\section{Revista de Sociologia e Política}

\author{
Ricardo Luiz Mendes Ribeiro
}

\begin{abstract}
RESUMO
O artigo tem como objetivo analisar o processo de refundação do Partido da Frente Liberal (PFL), que resultou na troca de comando do partido e na substituição da denominação anterior da legenda por Democratas (DEM), em março de 2007. A hipótese principal é que a transferência do PFL para a oposição, a partir de 2003, fato inédito na história do partido, decorrente da chegada do Partido dos Trabalhadores (PT) ao poder federal, foi o evento determinante para a decisão de seus dirigentes de tentar dar nova imagem e identidade ao PFL. Argumenta-se também que a refundação teve como objetivo reposicionar o PFL no mercado político eleitoral brasileiro, de modo que pudesse atrair o apoio do eleitorado das cidades de médio e grande porte. Mostra-se que a passagem para a oposição desencadeou o enfraquecimento do PFL. Entrevistas com dirigentes e políticos do partido, além de documentos, material de divulgação e pesquisas de opinião pública produzidos pelo PFL/DEM foram utilizados para a análise e descrição da refundação do PFL. Dados acerca da migração partidária e do desempenho eleitoral do partido antes e depois da passagem à oposição ao governo Lula também foram empregados. Mostra-se que a passagem para a oposição desencadeou o enfraquecimento do PFL. Dois movimentos conjugados provocaram o retraimento do partido: (i) a transferência de políticos pefelistas para legendas aliadas ao governo Lula; (ii) o mau desempenho eleitoral na região Nordeste, reduto tradicional do PFL em sua fase governista e que passou a ser progressivamente dominado por partidos que apoiavam a administração petista. Por fim, com base nos resultados das eleições municipais de 2000, 2004 e 2008, apresenta-se dados e testes estatísticos que sustentam a ideia de que os municípios menos desenvolvidos, menos populosos, localizados no Nordeste e cujas economias são mais dependentes do setor público possuem viés governista. Isto é, nessas localidades, mais do que no restante do país, o poder local tende a alinhar-se com o poder federal. Tal tendência parece fornecer uma boa explicação para o retraimento do PFL nos municípios com as características acima definidas. Os resultados aqui apresentados indicam a centralidade do poder federal no sistema político brasileiro e a dificuldade de sobrevivência de um partido de oposição ao governo federal, especialmente quando não controla governos estaduais importantes, como foi o caso do PFL a partir de 2006.
\end{abstract}

PALAVRAS-CHAVE: partido político; sistema partidário; PFL; eleições municipais; governismo

Recebido em 7 de Junho de 2012. Aprovado em 31 de Outubro de 2012.

\section{Introdução ${ }^{1}$}

\footnotetext{
${ }^{1}$ Agradeço aos comentários e sugestões de dois pareceristas anônimos da Revista de Sociologia e Política que muito contribuíram para a versão final do artigo. Naturalmente, lacunas, incongruências e outras falhas remanescentes são de minha inteira responsabilidade.
}

$\mathrm{E}$ m 1995, o jornalista Otavio Frias Filho, em sua coluna semanal no jornal Folha de São Paulo, tratou do projeto "PFL 2000" lançado alguns dias antes pelo comando da legenda para prepará-la para o novo milênio (Frias Filho 1995). De maneira jocosa, Frias Filho escreveu que o partido, o qual, segundo ele, estava no poder há 500 anos, não precisava preocupar-se com o futuro, pois este certamente lhe seria favorável.

Em 1999, Gabriela da Silva Tarouco finalizou sua dissertação de Mestrado em Ciência Política, cujo tema foi o Partido da Frente Liberal (PFL), com a seguinte afirmação: "enfim, é possível afirmar que o PFL tem obtido êxito nas suas metas de fortalecimento, no desafio de transformar-se em um partido nacional, no propósito de ocupar um lugar próprio no cenário político brasileiro e na reunião de recursos para a viabilização de projetos mais ambiciosos para o futuro do partido, como, por exemplo, o lançamento de uma candidatura pró- 
${ }^{2}$ Sobre a participação do PFL na eleição de Tancredo Neves ver Cantanhêde (2001) e Dimenstein et alii (1985).

${ }^{3}$ Segundo Roma (2002), a aproximação entre os tucanos e o PFL, que gerou fortes resistências em setores do PSDB, não se deveu apenas à necessidade de fortalecer eleitoralmente a candidatura Fernando Henrique Cardoso. Decorreu também da afinidade em relação às reformas que Fernando Henrique estava disposto a levar adiante e para as quais precisava de apoio no Congresso.

${ }^{4}$ Citando pesquisa feita por ele no banco de dados bibliográficos Data Índice, que cobre 70 revistas científicas brasileiras na área de Ciências Sociais, Leal (2005, p. 15) constatou que em janeiro de 2003 havia 17 artigos em consulta sobre o PT. Curiosamente, em segundo lugar aparecia o PCB, com 15 registros, um partido pouco relevante no período pós ditadura militar. Almeida (2004, p. 2) também ressalta a parca literatura a respeito dos partidos conservadores ou de direita no Brasil vis-à-vis os de esquerda. A preferência por estudar partidos de esquerda não parece estar restrita ao Brasil. Wolinetz (2002, p. 2070), por exemplo, diz que "we [political scientists] pay more attention to parties of the left than parties of the right" ("Nós [cientistas politicos], prestamos mais atenção aos partidos de esquerda do que os de direita"). Power (2000, p. 5) diz praticamente o mesmo a respeito da Ciência Política na América Latina. pria para a Presidência da República nas próximas eleições" (Tarouco 1999, p. 103).

Pouco mais de uma década após as previsões otimistas de Frias Filho e Tarouco, a situação do PFL, agora sob a denominação Democratas, ou DEM, como ficou mais conhecido, é bastante diversa. Já não se pode dizer que o partido está no poder há mais de 500 anos e não se vislumbram projetos muito ambiciosos para o futuro da legenda. Ao contrário, na crônica política jornalística tornou-se corriqueiro especular sobre a possibilidade de o DEM agregar-se ao PMDB, ou ao PSDB, ou de simplesmente desaparecer por causa da debandada de seus políticos.

A chegada do PT ao poder nacional, em 2003, marcou o início do rápido e acentuado processo de declínio do PFL. Essa é a hipótese principal deste artigo, cujo objetivo é analisar o processo de refundação do PFL, que resultou na troca do nome do partido para Democratas, ou DEM.

Até a passagem para a oposição, o PFL foi consistentemente o segundo maior partido do Congresso, atrás apenas do PMDB. Chegou a superar o PMDB em alguns momentos, entre 1998 e 2002. Foi também o segundo maior partido no plano municipal, além de ter eleito 23 governadores. Participou ainda, com cargos ministeriais, dos governos de todos os Presidentes da República desde 1985. Foi, por fim, fundamental em dois momentos importantes na história política recente do país: a eleição de Tancredo Neves no Colégio Eleitoral em $1985^{2}$, e a implementação da agenda de reformas de cunho liberal e pró-mercado levadas adiante pelo governo Fernando Henrique Cardoso ${ }^{3}$.

Apesar da importância do partido, o PFL foi pouco estudado pela Ciência Política brasileira. Aliás, existem poucos trabalhos sobre partidos conservadores no Brasil. Os partidos de esquerda costumam receber mais atenção dos pesquisadores brasileiros ${ }^{4}$.

Entre os partidos considerados conservadores, a UDN foi objeto de estudo de Benevides (1981), enquanto Hipólito (1985) e Lippi (1973) analisaram a trajetória do PSD. Ainda com foco no período pós-getulista e pré-militar, Sampaio (1982) abordou o PSP e o ademarismo. Mainwaring, Meneguello e Power (2000), por sua vez, são autores de livro que trata de maneira conjunta os partidos conservadores brasileiros contemporâneos. Mais recentemente, Almeida (2004) estudou a origem e a trajetória do PPB.

Quanto ao PFL, foi tema de um artigo de Lavareda (1985), no qual analisa a participação de alguns governadores nordestinos na dissidência aberta no PDS e que resultou na criação do PFL; de um livro de Cantanhêde (2001), onde a história da legenda é contada de maneira resumida; de uma dissertação de mestrado, na qual Tarouco (1999) trata da trajetória do partido até o final da década de 1990, momento no qual o partido atingiu o apogeu do ponto de vista de sua força parlamentar e não havia ainda passado pela experiência de fazer oposição ao governo federal. Tarouco (2002) também publicou um texto sobre o PFL, que é um desdobramento de sua dissertação de mestrado; e de duas teses de doutorado, Campos (2002), que examina o PFL de Pernambuco, e Corbellini (2005), que analisa a trajetória do partido de 1984 a 2002. Sobre o DEM, salvo engano, o único texto acadêmico já produzido foi a dissertação de mestrado de Ribeiro (2011).

Na sequência desta introdução, o processo de refundação do PFL será descrito de maneira resumida com base em documentos do partido e em entrevistas realizadas com dirigentes partidários e cientistas políticos relacionados à 
${ }^{5}$ A relação de entrevistas está no Apêndice.

\section{A refundação do PFL}

legenda ${ }^{5}$. Em seguida, serão apresentadas evidências empíricas que sustentam a hipótese de que a transferência para a oposição acarretou a decadência do partido. As considerações finais trarão a síntese das análises e descobertas e algumas considerações a respeito do atual cenário político brasileiro.

Em 28 de março de 2007, a Executiva Nacional do PFL aprovou por unanimidade a troca de nome do partido. Saiu de cena o Partido da Frente Liberal e entrou o Democratas, ou DEM, na forma abreviada pela qual passou a ser tratado mais comumente.

Para a cúpula do partido, a substituição do PFL pelo DEM não foi apenas uma troca de nome. Foi o ponto de chegada de um processo de "refundação" da legenda que, segundo documentos da legenda, teve início em 2004.

O objetivo da "refundação" e da troca de nome foi reposicionar a legenda no mercado político brasileiro e, principalmente, dar-lhe nova identidade frente ao eleitor. Como reconheceu o ex-senador Jorge Bornhausen no documento que sintetizou os princípios do nascente DEM, todo esse processo teve como motivação fundamental transformar a imagem do partido perante o eleitorado. $\mathrm{Na}$ introdução do documento, o então presidente do partido diz que "o PFL foi criado em sintonia com o sentimento do povo brasileiro pela democracia e sua história. Esteve e deve continuar associada ao compromisso da mudança. [...] Não basta que a história e os compromissos com a mudança tenham sido a marca da trajetória partidária. É necessário que a imagem do partido deva ser percebida pela opinião pública. [...] A sintonia com o desejo de mudança na sociedade brasileira e a imagem dela decorrente exige o reposicionamento do PFL que significa um processo natural e necessário de atualização de nosso ideário e a conseqüente renovação do compromisso original de mudança dentro do quadro democrático e frente aos novos desafios da sociedade brasileira" (PFL 2007, p. 4).

A troca do nome e a tentativa de dar nova identidade à sigla foram amparadas por uma pesquisa de opinião pública conduzida pela empresa MCI, presidida pelo cientista político Antônio Lavareda, cujos resultados mostraram que a sigla PFL, além de relativamente pouco conhecida, ainda estava associada de maneira negativa ao regime militar e carregava o estigma de ser um partido de direita.

A ideia de refundar o PFL começou a ser de fato implementada em 2004, embora a intenção de reformular o partido e de mudar o seu nome já tivesse sido discutida pelas lideranças da legenda em 2000, quando chegaram até a aventar a possibilidade de trocar o nome da agremiação para PSL (Partido Social Liberal) (cf. Cantanhêde 2000, p. 87). A transição para a oposição deu o empurrão necessário para desencadear o processo.

Jorge Bornhausen foi o principal idealizador e condutor do processo de refundação. "Esse momento [da refundação] foi muito refletido, principalmente por mim", disse o senador. "Eu estava na presidência do partido há dez anos e eu sentia que havia sempre uma campanha negativa em relação ao partido pelo fato de nós sermos os seus principais líderes desde a fundação e de termos participado dos governos militares" (Entrevista).

Apagar, ou ao menos amenizar, os vínculos históricos do PFL com o regime militar foi, portanto, um dos objetivos da refundação. Para tanto, ficou 
definido que haveria a troca de comando do partido com a ascensão de uma nova geração de políticos. A sucessão geracional ficou marcada pela indicação do deputado federal Rodrigo Maia, então com 37 anos, para a presidência do DEM.

Antônio Lavareda ressaltou esse ponto relacionado à refundação do partido. Segundo ele, Bornhausen vislumbrou que a mudança de nome deveria ser feita de maneira concomitante à ascensão de novos nomes na burocracia partidária. Seria uma forma de distanciar o PFL de seu passado relacionado ao período militar. "O comando do partido foi às mãos de um punhado de jovens deputados, alguns deles sequer nascidos da época do regime militar e que teriam então uma maior sintonia com esse novo invólucro, digamos assim, da legenda. O presidente Rodrigo Maia, por exemplo, é um garoto filho de um exilado político" (entrevista ao autor)

Segundo Lavareda, "o PFL sempre foi visto pela imprensa como o partido das forças políticas que estiveram no poder durante o período autoritário". Essa versão, excessivamente simplificada da trajetória política do sistema partidário brasileiro", funcionaria, de acordo com ele, como um "marcador" ideológico do sistema partidário, ao localizar o PFL na ponta direita do espectro ideológico. (Entrevista).

Ainda de acordo com Lavareda, "entre os grandes partidos, foi a primeira mudança geracional deliberada. Nunca tinha ocorrido na história política partidária brasileira. Fazer isso de uma forma pensada, estruturada, selecionar um punhado de jovens, parece simples, mas visto de fora, com cuidado, é uma manobra de engenharia política notável, no meu entendimento. E o mérito disso é do comando do senador Bornhausen. É óbvio que os demais membros do comando do PFL partilharam com ele essa ideia, mas quem a concebeu foi o senador Bornhausen" (Entrevista).

O Partido Popular (PP) espanhol e o Partido Social Democrata (PSD) português serviram de modelo para o processo de refundação idealizado por Bornhausen. Conforme ele disse na entrevista, "em razão dos contatos que eu tinha com o PP da Espanha e com o PSD de Portugal, eu fui vendo o modelo deles. Ambos se refundaram. E ambos tiveram nascimentos semelhantes ao nosso. O primeiro presidente e fundador do PP, Dom Manoel Fraga, quando este ainda não se chamava PP, foi um ex-ministro da Justiça do [General Francisco] Franco, como nós, Marco [Maciel], Guilherme [Palmeira], eu, o [José] Sarney, havíamos sido governo durante o período do regime militar. Então, em determinado momento, o Manoel Fraga fez a refundação do partido. Transformou-o em PP e o entregou à nova geração, liderada pelo José Maria Aznar. Isso fez com que o partido ganhasse nova vida. Já na segunda eleição sob a liderança do Aznar, o PP chegou ao governo da Espanha. Em Portugal se deu um processo idêntico. O PSD tinha líderes ligados à ditadura de [Antônio] Salazar e também fez sua refundação. Esses modelos serviram de base para a nossa refundação" (Entrevista).

Mas nem todos os setores do PFL regiram com entusiasmo à ideia da refundação. Não houve propriamente oposição, visto que Antônio Carlos Magalhães, o principal contendor de Bornhausen dentro do PFL e única liderança pefelista que foi capaz de contrapor-se com algum sucesso ao predomínio da aliança Bornhausen-Maciel que dominou o partido praticamente desde a sua fundação, já estava politicamente fragilizado. Mesmo assim, no começo de 2005, Antônio Carlos Magalhães dizia que a discussão a respeito da troca do nome do partido não era importante. Para ele, o importante para o partido não 
era mudar de estatuto, de sigla ou arrumar um símbolo - cogitava-se à época que o PFL poderia adotar o canário da terra como símbolo - "é arranjar votos e ganhar eleições. Nosso problema não é nada disso. É que o partido sempre foi mais forte no Nordeste do que no Sul e no Sudeste. Mas está perdendo substância, ou seja, votos, em Pernambuco, no Ceará, no Piauí e agora no Maranhão", concluiu o senador baiano (Duas décadas depois, PFL anuncia 'refundação' 2005).

Quando Bornhausen resolveu levar adiante o projeto de refundação do partido, a reação de Antônio Carlos Magalhães foi equivalente à de grande parte dos pefelistas: apoio e adesão, mais reticentes que entusiasmados. Como disse o deputado José Carlos Aleluia em entrevista, a reação de lideranças importantes e mais antigas do partido, que ele não quis identificar, foi de "ceticismo".

O ceticismo transparece, por exemplo, na declaração do senador José Agripino Maia em entrevista. Questionado a respeito de sua avaliação sobre o processo de refundação do partido, ele prontamente me corrigiu, "não é refundação. É atualização programática. Eu acho que refundação é um termo muito pesado. [...] Não é refundação. Isso é atualização de normas e procedimentos e de formulação programática, em função das mudanças que ocorreram no Brasil e no mundo nos últimos anos" (Entrevista).

E mesmo Saulo Queiroz, ex-secretário geral do partido, sempre muito próximo a Jorge Bornhausen, revelou na entrevista opinião negativa a respeito da refundação do partido. Instado a comparar a fundação e a refundação do PFL, Queiros disse que "não tem nada a ver. A fundação do PFL aconteceu numa conjuntura política importantíssima para o país. Foi determinante no apressamento da transição democrática. [...] Quanto à refundação, tem várias razões. Nenhuma delas é importante. Nenhuma delas eu diria que foi um acerto. Uma delas é que a marca PFL se estigmatizou com um partido de direita que apoiou o regime militar. Essa foi a principal razão [para a refundação e mudança de nome]. Em segundo lugar, houve o objetivo de tentar revitalizar o partido, oferecer uma coisa nova, mudar o comando, colocar gente nova. É aquele negócio, mudar o guarda roupa, tomar um banho de loja. Houve mudança de nome, mas não mudou absolutamente nada na essência" (Entrevista).

A troca de nome e a sucessão geracional no comando do partido também foram vistas com alguma desconfiança pela base do partido, pelos membros dos diretórios estaduais e locais do PFL. Segundo o relatório da MCI, a maioria dos candidatos pefelistas a prefeito na eleição de 2004 ouvidos pela empresa repudiou a ideia de mudar o nome do partido (MCI 2004, p. 156).

O senador José Agripino Maia disse que a refundação do partido, que ele chama de "atualização de programa", não foi discutida com a base do PFL, foi conduzida pelos "ideólogos [do partido], aqueles que formulam o pensamento e que o expõe à sua base" (Entrevista).

De acordo com o deputado José Carlos Aleluia, "as bases resistiram um pouco [ao processo de refundação]. Principalmente no Nordeste, na Bahia. O PFL era um nome bonito. Houve sim certa reação contrária" (Entrevista). Lavareda também disse que "os setores mais tradicionais do partido [localizados no Nordeste] até hoje lastimam a perda dessa marca [PFL]". (Entrevista).

Até mesmo Jorge Bornhausen reconheceu que a chamada base do partido resistiu à refundação. "Houve um pouco de desconfiança [da base do partido], uma certa perplexidade. Mas a determinação firme no sentido de fazer venceu esses obstáculos. [...] Acho que [a resistência] era natural. As pessoas estão 
voltadas para a estabilidade e já estavam acostumadas às lideranças do partido. Colocavam em dúvida a possibilidade de a nova geração tocar o partido" (Entrevista).

A menção à "determinação firme" de fazer a refundação do partido trás à tona uma característica histórica importante do PFL, relacionada à maneira como o partido se constituiu. O PFL, desde a sua fundação, estruturou-se como um partido organizado de cima para baixo e de origem interna, na nomenclatura de Duverger, no qual a cúpula manteve elevado grau de controle sobre as instâncias regionais da legenda. Em 14 de seus 22 anos de existência, o PFL foi presidido por Jorge Bornhausen "com mão de ferro", expressão amplamente utilizada pela imprensa para caracterizar a maneira como o ex-senador catarinense comandou o PFL. Por certo, Bornhausen e sua "determinação firme" não teriam ficado tanto tempo na direção do partido se não tivessem o respaldo da maioria pefelista. Seu principal aliado no PFL foi Marco Maciel. A dupla Bornhausen-Maciel controlou o PFL praticamente ao longo de toda a sua existência. Antônio Carlos Magalhães foi a única liderança importante que se contrapôs à dupla Bornhausen-Maciel dentro do PFL. A diferença entre eles remonta à fundação do partido.

O relacionamento entre Jorge Bornhausen e Antônio Carlos Magalhães sempre foi tumultuado. Antônio Carlos Magalhães não fez parte do grupo que fundou o PFL, em 1985, embora também tenha apoiado a eleição de Tancredo Neves contra Paulo Maluf. Ele aderiu ao PFL apenas em 6 de janeiro de 1986, praticamente um ano depois da fundação do partido. Para tanto, obteve de Bornhausen, Marco Maciel, Aureliano Chaves e Guilherme Palmeira, os principais líderes pefelistas naquele momento, a garantia de que teria liberdade de ação dentro da legenda (Cantanhêde 2001, p. 46). A entrada de Antônio Carlos Magalhães no PFL foi descrita dessa maneira por Jorge Bornhausen: "o senador Antônio Carlos Magalhães não foi fundador do partido. Ele permaneceu no PDS. Graças à sua habilidade política e ao seu jogo pessoal, ele negociou o Ministério das Comunicações para ele. Apesar da grande resistência do PMDB, entrou no ministério na cota pessoal do Tancredo, negociada por ele. E, portanto, ele tinha ligação com a fundação do partido. Ele apoiou Andreazza. Após a vitória do Maluf na convenção do PDS, ele procurou o Tancredo para fazer essa negociação política. Quando eu estava na presidência do partido, o presidente José Sarney me chamou e disse 'olha, está na hora de você levar o Antônio Carlos para o PFL'. Eu fui conversar com o Antônio Carlos e ele realmente queria entrar para o PFL, mas exigiu, pela sua força política, que ficasse com o comando do partido. Aí nos tivemos que fazer uma difícil negociação interna. Foi uma negociação dificílima, mas ele entrou no partido, embora sem a posição de comando que almejava" (Entrevista).

Apesar da divisão e dos conflitos entre as facções lideradas por Bornhausen-Maciel e por Antônio Carlos Magalhães, o PFL foi um partido coeso, especialmente no Congresso, onde suas bancadas na Câmara e no Senado vo-

${ }^{6}$ Sobre o comportamento do PFL nas votações no Congresso, ver Figueiredo e Limongi (1999, p. 112). Sobre a manutenção da coesão do partido a despeito dos conflitos entre as alas de Bornhausen-Maciel e de Antônio Carlos Magalhães, ver Corbelline (2005, p. 160-165). tavam quase sempre alinhadas com a direção do partido ${ }^{6}$. Paradoxalmente, a coesão teve como base justamente o acordo fechado quando da integração de Magalhães à legenda, o qual possibilitou a convivência, não imune a atritos, entre o grupo do político baiano e de Bornhausen-Maciel. Antônio Carlos Magalhães não conseguiu assumir o comando do PFL, mas recebeu garantias de que teria grande liberdade de ação dentro do partido.

$\mathrm{O}$ acordo esteve em vias de romper-se algumas vezes. O momento mais crítico ocorreu em 2003, quando Bornhausen propôs a expulsão de Antônio 
Carlos Magalhães do PFL em virtude dos gestos feitos pelo senador baiano na direção do possível apoio ao governo Lula. Para os objetivos deste artigo, importa assinalar, como já mencionado acima, que Antônio Carlos Magalhães era a única liderança com força suficiente para obstaculizar os planos de refundação do partido conduzidos por Bornhausen. Contudo, no momento da transição do PFL para o DEM, Magalhães já estava desgastado por causa da morte de Luis Eduardo Magalhães, pela renuncia ao Senado, em 2001, e pela derrota de Paulo Souto na eleição de governador da Bahia, em 2006. Consequentemente, não houve quem, dentro do PFL, pudesse resistir à ideia da refundação. Tanto mais porque a escolha de Rodrigo Maia, como presidente da nova sigla, agregou o apoio de Cesar Maia, então prefeito do Rio de Janeiro e figura importante no partido, à refundação.

\section{A mudança do nome}

${ }^{7}$ Cantanhêde (2001, p. 87), destaca que o termo liberal aplicado aos dissidentes do PDS na época em que fundaram o PFL tinha uma conotação mais política do que econômica. Referia-se à opo-
Além de pesquisar sobre a imagem do partido, a MCI também testou a ideia da mudança do nome do partido. A pesquisa quantitativa realizada pela empresa mostrou que, à exceção do PT, era muito grande o grau de desconhecimento da população a respeito do significado das siglas dos principais partidos brasileiros. No que diz respeito ao PFL, 55\% dos entrevistados disseram que não sabiam ou não responderam. 22\% responderam errado e apenas $23 \%$ souberam dizer que PFL significava "Partido da Frente Liberal". Tais percentuais foram semelhantes aos obtidos pelo PSDB e PMDB e contrastam fortemente com o que ocorria em relação ao PT. 64\% das pessoas ouvidas pelo MCI disseram corretamente que PT era o "Partido dos Trabalhadores". Assim, a princípio, a troca de nome, do ponto de vista da opinião pública em geral, não acarretaria danos ao partido.

Mas a mudança de nome foi condenada pelos chamados formadores de opinião, grupo composto por jornalistas e articulistas de TV, rádio e jornal, bem como sociólogos e cientistas políticos ouvidos em entrevistas pela MCI. Essas pessoas qualificaram a troca de nome como uma "tentativa de fugir do passivo de imagem com a adoção de uma nova denominação. [...] Entre os formadores, a ideia da troca do nome chegou a ser considerada uma atitude 'condenável', 'oportunista' e 'comum aos partidos de direita'” (MCI 2004, p. 155). A possibilidade de o partido mudar de nome também não foi muito bem recebida pelas lideranças partidárias entrevistadas, embora a ideia não tenha sido rechaçada com tanto vigor, como ocorreu entre os formadores de opinião.

Especificamente sobre o termo "liberal", a avaliação da MCI foi que, entre os formadores de opinião, a imagem de que o PFL era um partido liberal já estaria plenamente consolidada. Assim, o sumiço do "liberal" seria indiferente. Já entre o conjunto das pessoas entrevistadas na pesquisa quantitativa prevalecia o desconhecimento a respeito do significado da palavra, que aparecia comumente associada a "liberalidade" ou à "falta de regras". Portanto, também para o grande público, a ausência do termo "liberal" não provocaria grande impacto, segundo a avaliação da MCI. Diante dessas evidências, o relatório concluiu que "alterar a marca PFL poderia, neste momento, mais prejudicar do que contribuir para o reposicionamento partidário" (idem, p. 156).

A tese da pouca importância da presença da palavra "liberal" no nome do partido foi incorporada ao discurso de Jorge Bornhausen. Perguntado a respeito da polêmica ${ }^{8}$ provocada pela supressão do termo liberal no novo nome do partido, ele disse que "o importante não é o nome 'liberal'. O importante é a 
sição desse grupo aos "radicais" e "conservadores" que apoiavam Paulo Maluf.

${ }^{8}$ A respeito dessa polêmica, ver artigo de Rodrigo Maia publicado no jornal Folha de S. Paulo (11.dez.2007).

${ }^{9}$ Segundo relato de Cantanhêde (2001, p. 86), o termo "Frente Liberal" foi cunhado pela jornalista Maria Inês Nassif, então no Jornal do Brasil, com o intuito de identificar com uma denominação sucinta o grupo que a imprensa chamava de "deputados do movimento dissidente do PDS" ou de "dissidência parlamentar governista". O termo pegou. Passou a ser adotado por toda a imprensa e acabou sendo incorporado ao nome do partido. ideia liberal. E a ideia liberal foi mantida no documento que foi feito na refundação" (Entrevista).

Opinião semelhante foi revelada pelo senador José Agripino Maia. Segundo ele, não havia razão para manter o termo liberal pois este obrigava o partido a "ficar na defensiva", dada a carga negativa associada ao liberalismo no Brasil. E, como a adesão do partido aos ideais liberais fosse amplamente reconhecida, manter o "termo liberal não era necessário" (Entrevista). Conforme relatou Antônio Lavareda, em entrevista, a ideia de mudar o nome do partido, embora tivesse sido rejeitada pela pesquisa da MCI, foi retomada logo após a eleição de 2006.

O incômodo dos pefelistas com a denominação "Partido da Frente Liberal" era antigo, como indica declaração de Marco Maciel em entrevista. Segundo o ex-senador pernambucano, "nós [os dissidentes do PDS] éramos a chamada Frente Liberal. Quando precisamos definir o nome do partido, ficou 'Partido da Frente Liberal', uma denominação em si contraditória. Ora, nós somos partido ou somos uma frente?"9 (Entrevista).

Segundo explicação de Jorge Bornhausen, quando o partido foi formalizado, ficou acertado que o nome Partido da Frente Liberal seria apenas provisório: "A dissidência se chamava Frente Liberal. E nós tínhamos urgência de formar um partido. Então decidimos: 'vamos colocar Partido da Frente Liberal como nome provisório'. E o primeiro estatuto do partido estabeleceu isso, que o nome seria provisório" (Entrevista).

O cientista político Antônio Lavareda também comentou a incoerência de acoplar-se os termos "partido" e "frente". "Partido da Frente Liberal era uma contradição em termos: partido da frente? O partido pode estar numa frente, mas o partido não pode ser o partido da frente. Já havia essa contradição desses termos lá atrás" (Entrevista). Na entrevista, Lavareda explicou que "passada a eleição de 2006, conversávamos eu o presidente do partido [Jorge Bornhausen] e uma ideia que eu já tinha tido antes voltou à baila. A partir daí ele [Bornhausen] pediu um estudo específico sobre isso. Fizemos uma pesquisa qualitativa e vários nomes e alternativas surgiram. Com base nesses resultados, eu apresentei ao partido a sugestão de um nome que, primeiro, não tivesse o nome 'partido' e, segundo, que fosse coerente com os resultados da pesquisa que fizemos para o partido em 2004. Então, o presidente [Bornhausen] pediu que eu fizesse uma apresentação sobre a proposta do novo nome para a executiva do partido. Eu fiz e o novo nome foi aprovado na reunião da executiva" (Entrevista).

As denominações testadas nos focus groups foram: PMD (Partido da $\mathrm{Mu}-$ dança Democrática), PML (Partido da Mudança Liberal), PRD (Partido da Renovação Democrática), PRL (Partido da Renovação Liberal), PLD (Partido Liberal Democrático), PDL (Partido Democrático Liberal), PLB (Partido Liberal do Brasil) e PCD (Partido de Centro Democrático). Percebe-se que o nome afinal escolhido - Democratas - não foi avaliado nos grupos. Mas o termo "democrático(a)" estava presente na maioria das opções testadas, o que levou Lavareda a sugeri-lo para os dirigentes do partido.

\section{A refundação sob a óptica da teoria dos partidos}

O ex-senador Marco Maciel, ao comentar a refundação do PFL, disse que "é fundamental fazermos uma coisa que não fizemos ainda: transformar um 
${ }^{10}$ Linz (2002), por exemplo, atribui a opinião negativa atualmente disseminada a respeito dos partidos, detectada em pesquisas de opinião em vários países, ao predomínio de uma visão idealizada e irrealista a respeito dos partidos que remete ao partido de massas.

11 "Considerava-se majoritariamente que a maioria dos partidos deveriam ser avaliados como partidos de massa ou, em uma versão mais moderna, como a variante catch-all dos partidos de massa. Esse não era apenas o modelo empírico básico, transformou-se também no modelo normativo básico: para muitos pesquisadores os partidos deveriam seguir esse modelo, organizar-se e comportar-se de acordo com ele. Consequentemente, quando não se encaixavam nos parâmetros dos partidos de massa, eram considerados, por definição, fracos ou deficientes".

12 “O partido de massa está morto".

${ }^{13}$ Na Ciência Política brasileira, Souza (1976) também inovou ao salientar a ligação entre partidos e Estado. O arcabouço teórico, os objetivos o tema e até a forma e estilo de argumentação de Souza são bastante diferentes dos de Katz e Mair, até porque praticamente 20 anos separam a obra dela da dos dois autores. Contu- partido de quadros em um partido de base. Temos bons quadros. Mas, mais do que quadros, temos que ter "bases" (Entrevista). A fala de Maciel remete-nos à clássica diferenciação feita por Duverger (1970) entre partidos de quadros e partidos de massa. Na classificação de Duverger, partidos de massa são exatamente os que têm "base", isto é, um conjunto amplo de eleitores e apoiadores que estão ligados entre si por laços sociais e de classe, compartilham interesses e ideologias, e sentem-se representados por uma determinada agremiação política. A "base" é um elemento essencial para classificar um partido como sendo "de massas". Portanto, quando Marco Maciel diz que o PFL - ou o DEM precisa de uma base, no fundo, sob a lente da teoria política, está afirmando que o objetivo do PFL era transformar-se em um partido de massas.

Levando-se em conta as origens e as características do PFL e, historicamente, dos partidos de massa, os quais foram na origem partidos socialistas e trabalhistas, parece um objetivo desprovido de sentido. Mas é possível entender a referência feita por Maciel ao considerar que os partidos de massa tornaram-se o paradigma normativo do que normalmente se espera de um partido político. Ao senso comum, partido deveria ser uma organização dotada de coerência ideológica e amparada por uma base relativamente estável de filiados e simpatizantes que se identificam com o partido em função de afinidade ideológicas ou de interesses ${ }^{10}$. O conceito de que partido de massas é o modelo ideal de partido tornou-se também forte na teoria política. Como dizem Katz e Mair (2009, p. 754), "it was widely assumed then that most parties could be understood as mass parties or as the more modern catch-all variant of mass parties. This was not only the key empirical model, it had become the key normative model: for many scholars this was what parties should be like, how they should be organized and behave, and to the extent that they did not meet the standards of a mass party, then they were, essentially by definition somehow weak or failing"11.

Porém, os partidos de massa já não são efetivamente o modelo de partido político predominante nas democracias representativas. Na verdade - e essa avaliação é praticamente consensual entre os estudiosos do assunto - foram substituídos por modelos de partido mais consentâneos às democracias contemporâneas. Katz e Mair (idem, p. 760) chegam a afirmar veementemente que "the mass party is dead"12.

Os próprios Katz e Mair (1995; 1996; 1997; 2009) foram responsáveis por criar um modelo de partido, segundo eles, mais adequado às atuais características da democracia representativa, caracterizada pelo predomínio das comunicações de massa, crescente personalização da política e certa embaralhação das divisões ideológicas entre as legendas. Trata-se do partido cartel. É um partido que encontra no Estado, e não na sociedade, as forças vitais, financeiras e políticas, para sobreviver e crescer. Nesse tipo de partido, os detentores de cargos no Estado, no poder Executivo ou no Parlamento - que Katz e Mair (1993) chamam de party in the public office - são mais importantes do que a base partidária $^{13}$.

A ligação com o Estado em sua fase governista levou Tarouco (1999) e Ribeiro (2011) a classificarem o PFL como um partido cartel. É uma classificação sujeita a críticas, uma vez que o ponto fundamental da argumentação de Katz e Mair é que o partido cartel, na verdade, faz parte de um sistema de proteção à entrada de partidos desafiantes às principais legendas já estabelecidas no mercado político. O termo cartel vem justamente da economia e das relações comerciais e negociais entre empresas. Representa a ideia de conluio 
do, têm como importante ponto em comum a ênfase à relação entre os partidos e o Estado e a crítica à escassa importância que os cientistas políticos costumam dar a essa dimensão da atividade partidária. entre empresas ou organizações, em princípio, concorrentes, mas que se unem e acordam estratégias e ações que visam a favorecê-las conjuntamente. Assim, não faz pleno sentido classificar uma determinada legenda como partido cartel. $\mathrm{O}$ mais adequado é falar em partidos cartel. O fato de o PFL ter entrado em crise após migrar para a oposição é uma indicação de que o sistema de cartelização dos partidos não foi eficaz em prover proteção a um de seus membros.

Outra maneira de classificar o PFL, antes e após a refundação, tem como base a contribuição de Wolinetz (2002). Wolinetz defende que a análise dos partidos seja feita com base em três tendências ou orientações a partir das quais seria possível caracterizar os partidos mais adequadamente tanto do ponto de vista de sua organização quanto de sua atuação política. Os partidos podem ter três orientações fundamentais. Podem ser vote-seeking, policy-seeking ou office-seeking. Essa classificação, informa Wolinetz, foi formulada originalmente por Strom (1990), para analisar a formação de coalizões partidárias.

Um partido vote-seeking é aquele que adota como principal objetivo conquistar o maior número possível de votos e ganhar eleições. Na vertente policy-seeking, o objetivo principal é defender uma política (ou políticas) pública (s). Já o partido office-seeking busca essencialmente conquistar acesso a cargos no governo mesmo que, para isso, seja obrigado a adotar estratégias não maximizadoras de voto, como por exemplo, abrir mão de candidaturas para compor coligações.

Wolinetz reconhece que nenhum partido adota exclusivamente uma dessas orientações e que estas tampouco são independentes. Normalmente, há uma combinação entre duas dessas orientações. Porém, segundo Wolinetz, é possível identificar ênfases diferenciadas a cada uma dessas orientações e, geralmente, pelo menos uma delas é colocada em segundo plano na estratégia dos partidos.

No esquema proposto por Wolinetz, as duas dimensões privilegiadas pelo PFL antes da ascensão petista ao poder nacional eram o office-seeking e o voteseeking. Mas a primeira delas era mais importante. O desempenho eleitoral servia com um instrumento, digamos assim, para garantir ao partido condições de pleitear espaço na base governista. Quando o PFL foi alijado do poder federal em decorrência da vitória petista de 2002, perdeu abruptamente uma das bases sobre as quais se sustentava o que, mais adiante, afetou também o desempenho do partido nas urnas. Criou-se assim um círculo vicioso do qual a legenda não conseguiu se livrar.

Alijado do poder, o partido tentou se reciclar. Usando o esquema proposto por Wolinetz, é possível afirmar que o surgimento do DEM foi uma tentativa de reforçar a faceta vote-seeking do partido buscando uma nova base, formada pelos extratos médios da população urbana das médias e grandes cidades. Assim, pode-se dizer que, na passagem do PFL para DEM, o partido buscou se reformular migrando da combinação office e vote-seeking para vote e policyseeking.

\section{O declínio na oposição}

A passagem do PFL para a oposição foi o evento determinante para a refundação do partido e para o surgimento do DEM. Segundo Lavareda "a refundação do PFL foi uma estratégia de sobrevivência na oposição" (Entrevista). Para os dirigentes pefelistas estava claro que a transferência para a oposição 
colocaria a legenda diante de um desafio complicado. Afinal, desde que surgiu, o PFL sempre manteve relações próximas com o poder federal, tendo participado de todos os ministérios formados pelos presidentes que governaram o Brasil do final do governo militar até a ascensão de Lula.

Nas entrevistas realizadas, surgiu com frequência a conviç̧ão de que a nova condição oposicionista assumida pelo PFL levaria o partido a perder terreno nas regiões onde era tradicionalmente mais forte, notadamente no Nordeste. Foi essa avaliação que impulsionou os dirigentes do partido a empenharem-se na tarefa de recriar o partido, dar-lhe nova imagem e reposicioná-lo no mercado político eleitoral brasileiro de modo a transformá-lo em representante das camadas médias da população dos centros urbanos do Sul e Sudeste, em vez dos grotões nordestinos.

Segundo Lavareda, a refundação do PFL foi decorrente da constatação feita pelos dirigentes do partido de que o PFL "inevitavelmente declinaria no seu mercado tradicional, nos grotões no Nordeste, nas regiões menos desenvolvidas. [...] Sentiam isso a partir do avanço do Bolsa Família, do PT e dos partidos aliados ao PT nesses segmentos. Então havia de se fazer um trade-off entre essa fonte tradicional de votos do partido, que estava inevitável e progressivamente sendo tomada pelos principais adversários do PFL, havia que compensar esse declínio avançando no eleitorado dos centros urbanos grandes e médios. Para isso foi necessário o reposicionamento do partido, do ponto de vista do ideário e da imagem" (Entrevista).

De acordo com Saulo Queiroz, “o PFL se enfraqueceu por uma razão geográfica objetiva. Nosso grande reduto era o Nordeste, que virou reduto do Lula. O Lula no primeiro mandato ganhou o Nordeste. Nós fomos varridos do mapa político a partir do momento em que na última eleição [2006] não elegemos sequer um governador no Nordeste" (Entrevista).

O deputado José Carlos Aleluia (BA) confirmou a ideia do trade-off citada por Lavareda. "Eu, desde o começo do governo Lula, fiz uma previsão, um prognóstico que acabou se confirmando. O Democratas perderia espaço político no Norte e no Nordeste e ganharia espaço no Centro-Oeste, no Sul e até no Sudeste. Nessas próximas eleições [2010], o partido deve diminuir um pouco no Nordeste, mas deve crescer em São Paulo. Deve ir bem também em Santa Catarina e manter o espaço que tem no Paraná e no Rio Grande do Sul" (Entrevista).

A previsão de Aleluia, contudo, não se cumpriu integralmente. De fato, o encolhimento do partido foi mais acentuado no Nordeste. Mas essa tendência não foi compensada em outras regiões. Ao contrário, conforme mostram as Tabelas 1 e 2, desde 2002, a cada nova eleição, o desempenho do partido nas urnas foi cadente em praticamente todas as regiões. A Tabela 1 mostra o percentual de deputados federais e estaduais eleitos pelo partido em relação ao total de cadeiras em disputa desde 1986. Já a Tabela 2, a seguir, traz o percentual de prefeitos e vereadores do PFL e do DEM. Nos dois casos, os resultados foram agregados por região.

As tabelas mostram que os melhores momentos do PFL na disputa eleitoral ocorreram quando o partido estava aliado a governos bem avaliados na época em que aconteceram as eleições. Isso aconteceu em 1986, primeira eleição disputada pelo recém fundado PFL, quando estava associado ao governo Sarney, que, embalado pelo efêmero sucesso do Plano Cruzado, gozava de elevada popularidade naquela ocasião. E voltou a repetir-se em 1998, ano da 


\footnotetext{
${ }^{14}$ No começo de 2002, o PFL rompeu com o governo FHC por causa da ação da Polícia Federal no escritório político de Roseana Sarney, pré-candidata do partido à Presidência da República. Na ocasião, a Polícia Federal encontrou $\mathrm{R} \$ 1,3$ milhão em espécie no cofre da empresa Lunus, de propriedade de Roseana e de seu marido. A origem do dinheiro não foi esclarecida. A exibição do dinheiro na mídia abalou a candidatura de Roseana, que desistiu da disputa pouco tempo depois.
}

Tabela 1 - Deputados estaduais e federais eleitos pelo PFL/DEM por região (\% do total de cadeiras)

\begin{tabular}{lccccccc}
\hline & $\mathbf{1 9 8 6}$ & $\mathbf{1 9 9 0}$ & $\mathbf{1 9 9 4}$ & $\mathbf{1 9 9 8}$ & $\mathbf{2 0 0 2}$ & $\mathbf{2 0 0 6}$ & $\mathbf{2 0 1 0}$ \\
& \multicolumn{7}{c}{ Deputados Estaduais } \\
\hline Norte & 15,9 & 9,2 & 13,5 & 16,2 & 9,2 & 8,1 & 5,9 \\
Nordeste & 38,4 & 27,9 & 26,1 & 20,8 & 17,9 & 14,4 & 7,3 \\
Sudeste & 17,2 & 10,3 & 6,6 & 12,9 & 7 & 10 & 6,6 \\
Sul & 12,8 & 10,1 & 8,7 & 16,2 & 10,7 & 10,1 & 9,4 \\
Centro Oeste & 20,2 & 12,4 & 13,3 & 9,7 & 8 & 10,6 & 6,2 \\
Brasil & 24,2 & 16,0 & 15,1 & 16,2 & 11,5 & 11,1 & 7,1 \\
& & \multicolumn{7}{c}{ Deputados Federais } & & \\
Norte & 28,6 & 12,3 & 12,3 & 26,2 & 16,9 & 13,8 & 9,2 \\
Nordeste & 39,1 & 32,5 & 33,8 & 31,1 & 29,1 & 17,9 & 9,9 \\
Sudeste & 14,8 & 7,1 & 9,5 & 14,5 & 10,1 & 8,9 & 6,1 \\
Sul & 13 & 10,4 & 13 & 13 & 6,5 & 13 & 7,8 \\
Centro Oeste & 24,4 & 14,6 & 7,3 & 12,2 & 14,6 & 7,3 & 12,2 \\
Brasil & 24,2 & 16,5 & 17,3 & 20,5 & 16,4 & 12,7 & 8,4 \\
\hline
\end{tabular}

Fonte: Nicolau (2010) e Tribunal Superior Eleitoral.

Tabela 2 - Vereadores e prefeitos eleitos pelo PFL/DEM por região (\% do total de cadeiras)

\begin{tabular}{|c|c|c|c|c|}
\hline & 1996 & 2000 & 2004 & 2008 \\
\hline & \multicolumn{4}{|c|}{ Vereadores } \\
\hline Norte & 14,8 & 17,2 & 8,3 & 8,7 \\
\hline Nordeste & 23 & 19,7 & 11,2 & 9,2 \\
\hline Sudeste & 17,6 & 18 & 12,2 & 10,5 \\
\hline Sul & 10,8 & 12,3 & 5,8 & 7,7 \\
\hline Centro Oeste & 13,9 & 15,7 & 7,4 & 9,5 \\
\hline \multirow[t]{2}{*}{ Brasil } & 17,4 & 17,1 & 9,6 & 9,3 \\
\hline & \multicolumn{4}{|c|}{ Prefeitos } \\
\hline Norte & 16 & 21,6 & 8,9 & 8,8 \\
\hline Nordeste & 24 & 24,8 & 23,2 & 8,6 \\
\hline Sudeste & 17 & 15,5 & 12,5 & 10,9 \\
\hline Sul & 9,4 & 13,3 & 7,2 & 6,6 \\
\hline Centro Oeste & 15,6 & 14,9 & 8,4 & 8,8 \\
\hline Brasil & 17,4 & 18,5 & 14,2 & 8,9 \\
\hline
\end{tabular}

Fonte: Nicolau (2010) e Tribunal Superior Eleitoral.

reeleição de Fernando Henrique Cardoso. Não foi possível obter dados sobre a eleição de vereadores e prefeitos agregados por região antes de 1996. Mas as informações disponíveis indicam que também em âmbito municipal o partido teve melhor desempenho nas urnas quando era o principal aliado do presidente Fernando Henrique Cardoso, ou seja, em 1996 e em 2000.

A fase descendente do partido tem início na eleição de 2002, quando o partido havia rompido com o governo $\mathrm{FHC}^{14}$. A eleição de Lula acabou por fechar definitivamente a porta do governo federal ao PFL. O senador Antônio Carlos Magalhães, ainda influente no partido, tentou aproximar-se do novo governo, mas a maioria do PFL decidiu que a legenda deveria ficar na oposição.

Segundo relato do senador Bornhausen, "em nota emitida em outubro de 2002, logo após a eleição, deve ter sido lá por 29 ou 30 de outubro, o PFL se colocou na oposição, o que desgostou alguns. Houve certa resistência. O próprio Antônio Carlos [Magalhães] queria retardar esse posicionamento. Mas foi uma nota firme. Porque, para mim, um princípio clássico da democracia é que quem ganha é governo e quem perde é oposição, a quem cabe fiscalizar o governo com responsabilidade" (Entrevista). 
Os dirigentes do PFL acusaram o governo de ter usado deliberadamente a Polícia Federal para derrubar a candidatura de Roseana, a fim de favorecer José Serra, précandidato do PSDB.
Antônio Lavareda, na entrevista concedida, disse que essa não era necessariamente a única opção para o partido. "Haveria sempre a alternativa de participar do governo, como o PMDB fez, e também o PP e outros partidos tão ou mais conservadores que o PFL", argumentou Lavareda. (Entrevista).

No entanto, o PFL não se acercou com o governo Lula e, assentado na oposição, o partido, como mostram as Tabelas 1 e 2, continuou a definhar a cada eleição que disputou desde então. Isso ocorreu de maneira quase ininterrupta em praticamente todas as regiões.

O recuo do PFL/DEM no Nordeste foi particularmente impressionante. Comparando-se 2010 a 1986, a participação do partido no total de deputados federais eleitos na região caiu 29,2 pontos percentuais. Se a base de comparação é 1998 , a queda foi menor (21,2 pontos), mas não se pode dizer que tenha sido inexpressiva. Em termos absolutos, o partido perdeu 44 deputados federais na região desde 1986, e 32 desde 1998. Em 2010, elegeu apenas 15 deputados no Nordeste. Quanto aos deputados estaduais, a redução foi de 29,2 pontos (base 1986), ou 106 deputados, e 13,5 pontos (base 1998), o que equivale a 46 deputados.

$\mathrm{Na}$ esfera municipal a história foi a mesma. O desempenho do PFL/DEM caiu de maneira mais acentuada no Nordeste. Entre 1986 e 2008, a participação dos vereadores pefelistas no total de eleitos no Nordeste caiu 13,8 pontos, o que equivale a 2687 vereadores. No caso dos prefeitos, a queda foi de 15,4 pontos (250 prefeitos).

Ainda com relação ao recuo no Nordeste, José Carlos Aleluia - um deputado baiano, ressalte-se -, comentou que "a classe dominante no Nordeste, os políticos da região, procuram o poder. Não estão em busca de ideias. São pragmáticos. Aproximar-se do governo é uma necessidade. Muitos municípios não conseguem sobreviver sem aderir ao poder" (Entrevista).

Gustavo Krause, outro político nordestino entrevistado, fez observação semelhante. Em entrevista, qualifica o governismo do sistema político brasileiro como "uma doença endêmica e epidêmica". Disse que viu isso ocorrer de modo avassalador na "província", referindo-se a Pernambuco, a partir do momento em que o PT chegou ao poder.

\section{O enfraquecimento decorrente da migração partidária}

A ideia de que a debilidade do PFL, após 2002, deveu-se à passagem do partido para a oposição é amparada, em primeiro lugar, por números da migração partidária que afetou a legenda. A saída de dezenas de deputados do partido a partir de 2003 ajudou a acelerar o processo de encolhimento do partido. Cinquenta deputados federais deixaram o PFL/DEM até 2010. Trinta e nove abandonaram o partido na legislatura 2003-2006 e outros 11 na legislatura 2007-2010. Entre esses não estão incluídos três deputados que entraram e saíram do partido durante a legislatura de 2003 e outros quatro que fizeram o mesmo na legislatura de 2007.

Em 2002, o PFL elegeu 84 deputados federais, 21 a menos do que em 1998. Apesar de ter diminuído, era uma bancada expressiva. Perdia apenas para o PT, que elegeu 91 deputados, e superava a do PMDB (74 deputados) e do PSDB (71 deputados). Como mostram o Gráfico 1, entre a eleição e a posse, 9 deputados deixaram o PFL. Outros 13 fizeram o mesmo em 2003. No final de 2006, a bancada pefelista estava reduzida a 61 deputados. Ou seja, 
${ }^{15}$ Essas visões negativas a respeito do sistema partidário brasileiro foram contestadas por vários trabalhos realizados nos últimos anos. Para uma síntese de alguns desses trabalhos ver Ribeiro (2011, p. 31-38).
Gráfico 1 - Deputados federais que deixaram o PFL nas legislaturas de 2003 e 2007
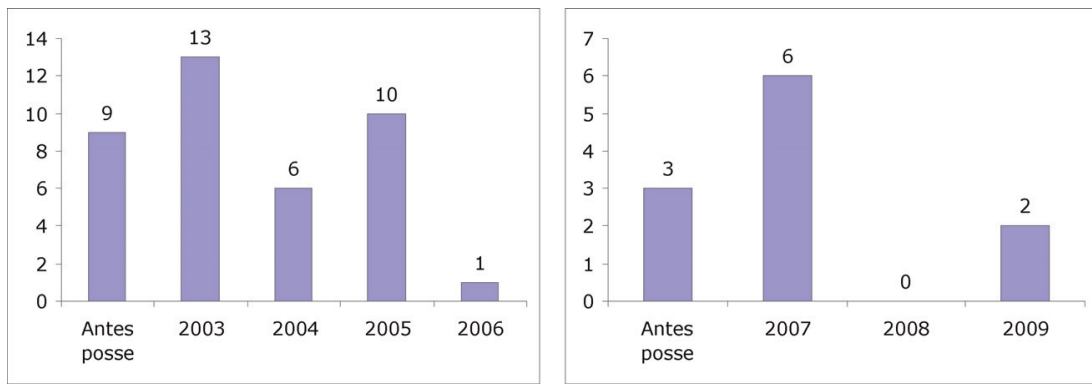

Fonte: Banco de Dados Legislativos do Centro Brasileiro de Análise e Planejamento (Cebrap).

durante a legislatura que teve início em 2003, o PFL perdeu mais deputados em virtude do troca-troca partidário (39 deputados) do que do resultado eleitoral (21 deputados, comparando-se o resultado da eleição de 1998 com a de 2002). A migração partidária também prejudicou o partido na legislatura seguinte, mas de maneira menos acentuada.

O chamado "troca-troca" partidário costuma ser apresentado na literatura como um indício da precariedade do sistema partidário brasileiro (Melo 2004; Lamounier 2005). Evidenciaria a falta de identidade dos partidos brasileiros que, de modo geral, seriam carentes de feições programáticas e ideológicas próprias, tornando-se pouco distintos entre si, além de incapazes de gerar identidades sólidas com o eleitorado (Kinzo 2005). Tais características enfraqueceriam os elos entre os partidos e os políticos a eles filiados. O sistema de eleição proporcional com lista aberta e voto uninominal utilizado no Brasil também contribuiria para debilitar a fidelidade dos políticos aos partidos que o elegeram (Ames 1995; Mainwaring 1999, p. 179-221) ${ }^{15}$.

Freitas (2008), no entanto, tem uma visão menos negativa a respeito da migração partidária. Ela rejeita a tese de que a migração comprovaria a fragilidade dos partidos brasileiros. Refuta também a ideia de que o fluxo migratório dar-se-ia inequivocamente no sentido da adesão a legendas governistas. Contudo, a conclusão de Freitas sobre a não existência de viés governista na mi-

Tabela 3 - Destino dos deputados federais que deixaram o PFL

\begin{tabular}{lccc}
\hline Partidos de Destino & $\mathbf{2 0 0 3}$ & $\begin{array}{c}\text { Legislaturas } \\
\mathbf{2 0 0 7}\end{array}$ & Total \\
\hline PL/PR & 14 & 5 & 19 \\
PTB & 7 & 1 & 8 \\
PP & 6 & 1 & 7 \\
PPS & 3 & 0 & 3 \\
PMDB & 1 & 2 & 3 \\
PSC & 2 & 0 & 2 \\
PV & 2 & 0 & 2 \\
PSB & 1 & 1 & 2 \\
PSDB & 2 & 0 & 2 \\
Sem partido & 1 & 0 & 1 \\
PRB & 0 & 1 & 1 \\
Total & 39 & 11 & 50 \\
\hline
\end{tabular}

Fonte: Banco de Dados Legislativos do Centro Brasileiro de Análise e Planejamento (Cebrap). 
${ }^{16}$ Em 27 de março de 2007, o TSE, em resposta a um questionamento proposto pelo PFL, sacramentou o entendimento de que os mandatos eletivos pertencem aos partidos. Consequentemente, a partir daquela data, políticos que se transferissem para outros partidos passaram a ficar sujeitos à perda de seus mandatos. A decisão do TSE foi confirmada posteriormente pelo Supremo Tribunal Federal (STF), em 4 de outubro de 2010 . gração partidária não se aplica ao PFL. A Tabela 3 mostra o destino dos deputados federais que deixaram o PFL desde 2003.

Na Legislatura 2003, 92\% dos deputados que deixaram o PFL transferiram-se para legendas aliadas ou próximas ao governo Lula. Na Legislatura de 2007, todos os deputados que deixaram o PFL filiaram-se a partidos aliados ao governo Lula.

Provavelmente, o PFL teria perdido mais parlamentares caso decisão do Tribunal Superior Eleitoral (TSE) não tivesse suspendido o livre trânsito de detentores de cargos eletivos entre as legendas ${ }^{16}$.

Em valores absolutos, a Bahia concentrou o maior número de deputados federais pefelistas migrantes. Foram seis na legislatura 2003 e outros cinco entre 2007 e 2009. Em segundo lugar, ficou o Maranhão. Em termos regionais, o Nordeste contribuiu com o maior número de dissidentes: 27, sendo 20 na Legislatura de 2003 e sete na legislatura de 2007. Sudeste e Norte ficaram em segundo e terceiro lugar, com dez e nove deputados, respectivamente. Porém, ponderando o número de deputados migrantes pelo de deputados eleitos em cada estado e região, a Bahia e o Nordeste perdem a liderança. Em alguns estados - Ceará (2003), Paraíba (2003 e 2007) e Rondônia (2003), a taxa de transferência para outros partidos foi de $100 \%$. Isto é, a bancada estadual pefelista reduziu-se a zero. Porém foram estados em que o PFL elegeu no máximo dois deputados. Em termos regionais, a taxa de migração foi maior no Norte e no Sudeste, na legislatura 2003, e no Nordeste, na legislatura 2007.

\section{O enfraquecimento nas bases tradicionais}

Outra maneira de vislumbrar os efeitos da transição do PFL para a oposição é analisar o desempenho do partido nas últimas três eleições municipais. Os dados eleitorais dessas eleições serão utilizados como subsídio para mostrar, por meio de análise descritiva de dados e também de modelos estatísticos, como o PFL foi perdendo força em seus redutos eleitorais mais tradicionais à medida que se distanciou do poder central. A escolha das eleições municipais para analisar os efeitos da passagem do PFL para a oposição decorre de dois fatores: (i) como o último - e único - candidato pefelista a presidente foi Aureliano Chaves, em 1989, não há como utilizar a eleição presidencial como base para a análise do desempenho do eleitoral do PFL; (ii) as eleições para a Câmara Federal e para o Senado também não são adequadas para os objetivos deste trabalho, pois não nos permite identificar com precisão a base eleitoral local dos candidatos eleitos pelo partido.

Na primeira dessas eleições municipais, em 2000, o PFL ainda era um partido governista. Nas duas últimas, 2004 e 2008, já havia passado à oposição. Em 2008, apresentou-se nas urnas pela primeira vez como DEM, após passar pelo processo de refundação, que tinha como um de seus objetivos alcançar um eleitorado diverso do que, historicamente, votava no partido.

A fim de avaliar os efeitos que a passagem à oposição acarretou à base eleitoral do PFL, partiu-se da hipótese de que há municípios com viés governista. O governismo é aqui definido em relação ao poder nacional. Ou seja, são considerados governistas os partidos que participavam da coligação que apoiava o governo federal na época da eleição.

Como desdobramento dessa hipótese inicial, assumiu-se que os municípios tendentemente governistas possuem as seguintes características: (i) estão loca- 
Tabela 4 - Deputados federais eleitos e que deixaram o PFL, por estado

\begin{tabular}{|c|c|c|c|c|c|c|}
\hline & \multicolumn{3}{|c|}{2003} & \multicolumn{3}{|c|}{2007} \\
\hline & Eleitos & Saíram & $\%$ & Eleitos & Saíram & $\%$ \\
\hline C. OESTE & 6 & 1 & 17 & 3 & 0 & 0 \\
\hline Distrito Federal & 1 & 0 & 0 & 2 & 0 & 0 \\
\hline Goiás & 3 & 1 & 33 & 1 & 0 & 0 \\
\hline M. G. do Sul & 1 & 0 & 0 & 0 & 0 & - \\
\hline Mato Grosso & 1 & 0 & 0 & 0 & 0 & - \\
\hline SUDESTE & 18 & 10 & 56 & 16 & $\mathbf{0}$ & $\mathbf{0}$ \\
\hline Espírito Santo & 0 & 0 & - & 0 & 0 & - \\
\hline Minas Gerais & 7 & 4 & 57 & 6 & 0 & 0 \\
\hline Rio de Janeiro & 4 & 2 & 50 & 5 & 0 & 0 \\
\hline São Paulo & 7 & 4 & 57 & 5 & 0 & 0 \\
\hline SUL & 5 & 1 & 20 & 10 & 2 & 20 \\
\hline Paraná & 2 & 0 & 0 & 5 & 0 & 0 \\
\hline R. G. do Sul & 1 & 0 & 0 & 2 & 0 & 0 \\
\hline Santa Catarina & 2 & 1 & 50 & 3 & 2 & 67 \\
\hline NORDESTE & 44 & 20 & 45 & 27 & 7 & 26 \\
\hline Alagoas & 2 & 1 & 50 & 2 & 1 & 50 \\
\hline Bahia & 19 & 6 & 32 & 13 & 5 & 38 \\
\hline Ceará & 2 & 2 & 100 & 0 & 0 & - \\
\hline Maranhão & 7 & 5 & 71 & 2 & 0 & 0 \\
\hline Paraíba & 1 & 1 & 100 & 1 & 1 & 100 \\
\hline Pernambuco & 5 & 2 & 40 & 3 & 0 & 0 \\
\hline Piauí & 4 & 2 & 50 & 2 & 0 & 0 \\
\hline R. G. do Norte & 2 & 1 & 50 & 1 & 0 & 0 \\
\hline Sergipe & 2 & 0 & 0 & 3 & 0 & 0 \\
\hline NORTE & 11 & 7 & 64 & 9 & 2 & 22 \\
\hline Acre & 0 & 0 & - & 0 & 0 & - \\
\hline Amapá & 0 & 0 & - & 1 & 0 & 0 \\
\hline Amazonas & 3 & 2 & 67 & 1 & 1 & 100 \\
\hline Pará & 1 & 0 & 0 & 2 & 0 & 0 \\
\hline Rondônia & 1 & 1 & 100 & 0 & 0 & - \\
\hline Roraima & 3 & 2 & 67 & 2 & 0 & 0 \\
\hline Tocantins & 3 & 2 & 67 & 3 & 1 & 33 \\
\hline BRASIL & 84 & 39 & 46 & 65 & 11 & 17 \\
\hline
\end{tabular}

Fonte: Banco de Dados Legislativos do Centro Brasileiro de Análise e Planejamento (Cebrap).

lizados principalmente no Nordeste; (ii) são pequenos e pouco desenvolvidos; (iii) sua economia é dependente do setor público. São características que definem o que se costuma chamar de "grotões", cidades pequenas, pobres, dependentes de recursos públicos e localizadas nas regiões menos desenvolvidas do país. Três autores justificam esse perfil traçado para os municípios teoricamente governistas.

O primeiro deles é Victor Nunes Leal (1993), para quem os municípios com as feições acima apresentadas seriam os mais propensos a fazer parte da engrenagem político-econômica analisada por ele, que atrelava os interesses dos mandatários políticos locais ao poder federal, com a intermediação do governo estadual. A situação político-institucional, econômica, social e demográfica do país alterou-se profundamente em relação à realidade que motivou o clássico estudo de Leal sobre o coronelismo no Brasil. A autonomia do poder local é maior nos dias de hoje do que nas primeiras décadas do século passado, período estudado por Leal. E o eleitor, mesmo nos grotões, provavelmente está menos sujeito ao poder do mandatário político local. Assim, se os municípios com as características acima definidas ainda expressam a propensão de seguir 
os ventos políticos que sopram na esfera federal, os mecanismos que conectam o poder local ao nacional são certamente distintos dos descritos por Leal. Mesmo assim, a político-dependência do poder local em relação ao poder federal, fenômeno estudado pelo autor, ainda parece subsistir no Brasil contemporâneo e este artigo apresenta evidências nesse sentido.

Já em Schwartzman (1982), essa político-dependência é apresentada como um fenômeno mais forte nas regiões localizadas ao norte de Minas Gerais. Seria um desdobramento do débil desenvolvimento econômico dessas regiões e das características históricas das relações entre o mercado e o Estado ali desenvolvidas. Nessas regiões, as relações políticas predominantes seriam do tipo de "cooptação", argumenta Schwartzman, e não de "representação", que estaria mais presente apenas em São Paulo. "O que a análise histórica sugere é que as elites regionais no Centro, Nordeste e, em certa medida, no Sul do país, tendem historicamente a se preocupar menos com a representação de seus interesses no centro político nacional do que com o seu acesso a posições de poder e prestígio em um regime político centralizado. Os esforços eventuais de autonomia local tendem geralmente a ser facilmente ou cooptados pelo centro, ou suprimido pelas elites locais com o apoio do governo central. [...] Um regime político baseado na centralização do poder e cooptação de setores mais ativos tende à excessiva burocratização e à política de distribuição de recursos entre clientelas eleitorais" (idem, p. 158).

A cooptação política é descrita por Schwartzman como um "sistema de participação política débil, dependente, controlado hierarquicamente, de cima para baixo" no qual a "participação política deixa de ser um direito e torna-se um benefício outorgado, em princípio revogável" e que tende a predominar em "contextos em que estruturas governamentais fortes e bem-estabelecidas antecedem historicamente os esforços de mobilização política de grupos sociais" (idem, p. 37) Assim, nesse sistema, "a administração pública é vista como um bem em si mesmo, e a organização governamental tem as características de um patrimônio a ser explorado e não de uma estrutura funcional a ser acionada para a obtenção de fins heterônimos" (idem, p. 37-38) e "quanto mais íntima a participação do líder na burocracia governamental, maior sua força política, já que terá mais recursos para manter o controle de suas bases" (idem, p. 39).

Segundo Schwartzman, em decorrência de sua formação histórica, São Paulo tornou-se uma espécie de território resistente ao patrimonialismo. Por conta disso, em São Paulo, cuja pujança econômica, excetuando-se o período da República Velha, não se traduziu, até a década de 1990, em força política proporcional na esfera de poder nacional, estariam concentradas forças sociais e políticas que, caso se tornassem hegemônicas no país, poderiam romper com

${ }^{17}$ Cardoso (1975, p. 72) fez uma avaliação semelhante à de Schwartzman. Ao comentar as perspectivas de evolução do Movimento Democrático Brasileiro (MDB) a partir da vitória obtida pelo partido na eleição de 1974 , Cardoso afirma que se o "MDB quiser marchar no sentido de constituir-se como um grande partido de massas terá que aumentar a participação popular em seus quadros, vincular-se mais às organizações de base [...], ampliar sua capacidade de represeno neopatrimonialismo ${ }^{17}$. "Parece que alguma forma de política de grupos de interesse (ou política de classe) está na raiz da maioria das versões contemporâneas de democracia política, e uma das conclusões que poderiam ser extraídas dessa análise seria por exemplo, que existiria somente uma forma de levar o Brasil para um sistema mais aberto de participação política: fomentar o papel de São Paulo na política nacional, ao longo de toda a sua estrutura de estratificação sócio-econômica, fazendo com que este sistema regional se expanda até predominar sobre as demais áreas do país, urbanas não-industriais e rurais" (ibidem).

O próprio autor reconhece que essa proposição é simplista. Porém, de acordo com ele, é uma abordagem que abre um horizonte interessante para a análise do modelo político brasileiro. 
tar interesses grupais importantes [...] e, especialmente, terá que atualizar constantemente a temática e a perspectiva oposicionista, evitando os riscos óbvios da cooptação e da política de conchavos na cúpula. A efetividade destes quesitos requer e depende de um grau elevado de democracia interna e de um sistema de capilaridade entre o partido e as organizações da sociedade civil. Esta última, apesar das conhecidas e reais limitações à sua vigência numa sociedade como a brasileira, se tem chances de existir (como tem) é a partir de, ou sobretudo em, São Paulo, estado industrializado e urbanizado" (ibidem; sem grifos no original).

\section{Evidências empíricas}

18 "Incumbência, como se percebe, parece ter um efeito importante sobre o padrão de voto. Como foi notado primeiramente por Zucco Jr. (2008), recentemente, todos os candidatos de partidos incumbentes conseguiram proporcionalmente maior parcela de votos em localidades pobres ao passo que o inverso ocorre para os principais partidos de oposição. Isso não significa que os partidos incumbentes sempre ganham as eleições em localidades mais pobres, pois seu nível médio de apoio pode variar por conta de diferentes razões. Isso sugere, contudo, que os incumbentes possuem uma vantagem intrínseca na busca pelo voto desses eleitores".

${ }^{19}$ Para a distinção entre partidos governistas e não governistas, foi utilizada a classificação apresentada na Tabela B.1 da dissertação de Freitas (2008, p. 120-124). A única diferença é o PTB ao final do governo Fernando Henrique Cardoso, que Freitas classifica como oposição e eu como governista. Decidiu-se situar o PTB no campo governista, em 2000, porque esse partido, à exceção dos dois últimos anos, apoiou fortemente o governo FHC desde o início. E mesmo no final, a semelhança das votações de sua bancada no Congresso, em relação à posição adotada pelo PSDB, continuou elevada $(78 \%$, segundo cálculo de Freitas).
Por fim, Zucco (2010), trabalhando com as eleições presidenciais de 1994 a 2010, chega à conclusão de que os eleitores dos municípios mais pobres e menos desenvolvidos do país parecem ter predisposição maior a votar no candidato governista, fenômeno que ele chama de "incumbency effect". "Incumbency, as it turns out, seems to have a conspicuous effect on electoral voting patterns. As first noted in Zucco Jr. (2008), all recent incumbent party candidates got a proportionally higher share of votes in poorer places while the reverse applies to the main party in opposition. This does not mean that the incumbent party candidate always wins elections in poorer places, as his average level of support can vary for many different reasons. It does suggest, however, that incumbents have a buit-in advantage in reaching these voters" 18 (Zucco 2010, p. 5)

A conclusão de Zucco corrobora, portanto, a ideia de que municípios mais pobres tendem a apresentar viés governista, neste caso expresso na decisão de voto de seus eleitores na disputa presidencial.

A análise descritiva dos dados relativos às eleições municipais de 2000, 2004 e 2008 leva em conta os números apresentados nas Tabelas 5, 6 e 7, a seguir. A Tabela 5 mostra o desempenho dos oito principais partidos brasileiros que, juntos, respondem por cerca de $90 \%$ dos prefeitos eleitos nas três eleições aqui consideradas. Os partidos foram divididos em governistas e não governistas ${ }^{19}$. Na primeira coluna são apresentados os resultados gerais, isto é, considerando-se o total de municípios para os quais foi possível encontrar os dados selecionados. Na segunda coluna, foram destacados apenas os municípios com menos de 20 mil habitantes. Na terceira, os municípios localizados no Nordeste. Na quarta, os municípios de IDH (Índice de Desenvolvimento Humano $)^{20}$ baixo, assim definidos como os que possuíam IDH abaixo da média menos um desvio padrão (IDH menor que 0,616 ). Na quinta coluna, estão contemplados os municípios de maior relação entre a contribuição da administração pública para o PIB municipal (APU) e o valor total do próprio PIB do município (APU/PIB $)^{21}$. Nesse caso, foram selecionados os municípios com APU/PIB superior a 0,403 (média mais um desvio padrão, calculados a partir da série completa $)^{22}$.

Mas qual é a relevância dos municípios pouco populosos, de baixo IDH e elevada relação APU/PIB no conjunto do eleitorado brasileiro? No contexto nacional, notadamente em relação às duas últimas características, não são muito importantes. Os municípios com menos de 20 mil habitantes abrigam 19,9\% de toda a população nacional. Para os de baixo IDH e elevada APU/PIB, o percentual cai expressivamente para $9,4 \%$ e $7,6 \%$, respectivamente. Portanto, em termos nacionais, pode-se dizer que o controle do poder nesses municípios não é relevante. A conclusão altera-se, no entanto, ao restringir-se a análise apenas ao Nordeste. Considerando somente as cidades nordestinas, a população dos municípios com menos de 20 mil habitantes corresponde a 25,5\% do total da região. A diferença em relação à esfera nacional é ainda mais acentuada para o IDH e APU/PIB. No Nordeste, a participação desse dois conjuntos de municípios sobe para 30,2\% e 19,7\%, respectivamente. Ou seja, no Nordeste, os municípios que possuem as características selecionadas respondem por $20 \%$ a 30\% de todo o eleitorado (assumindo que há plena correspondência entre número de habitantes e de eleitores). Não é uma parcela desprezível, nem para as disputas majoritárias, nem para as proporcionais. 
${ }^{20}$ Os valores do IDH são referentes a 2000, último ano em que essa informação está disponível em nível municipal.

${ }^{21}$ Para comentários a respeito do valor agregado da administração pública para o PIB municipal, ver páginas 45 a 48 de relatório do IBGE, "Análise dos resultados Produto Interno Bruto dos Municípios (2004-2008)". Disponível em: www.ibge.gov.br/home/esta tistica/economia/pibmunicipios/ 2004_2008/comentarios.pdf. Acesso em: 2.fev.2014.

${ }^{22}$ A variável relação APU/PIB para os municípios, até onde se sabe, está sendo utilizada pela primeira vez neste trabalho. Não há, portanto, um parâmetro estabelecido para definir a partir de qual valor pode-se dizer que essa relação é alta. Quanto ao IDH, no Relatório de Desenvolvimento Humano do PNUD de 2010, os países de IDH abaixo de 0,470 foram considerados de "desenvolvimento humano baixo". Contudo, apenas um município brasileiro possui IDH inferior a 0,470 . Esse, portanto não é um parâmetro que se pode aplicar a este trabalho. Assim, na falta de parâmetros conhecidos e utilizáveis, optou-se por um critério puramente estatístico para definir o que para nós significa IDH baixo e relação APU/PIB elevada.
Feita essa consideração, será analisada, em primeiro lugar, a situação do PFL ilustrada nas Tabelas 5 e 6. Em 2000 e em 2004, nota-se nitidamente que o desempenho do partido é bem melhor nos municípios caracterizados como de viés potencialmente governista (menos de 20 mil habitantes, nordestinos, IDH baixo e APU alto) do que no conjunto de todos os municípios. Em 2000, o PFL conseguiu eleger $18,5 \%$ dos prefeitos de todas as cidades do país. Já entre os municípios do menos de 20 mil habitantes, conquistou 19,8\% das prefeituras em disputa. E o desempenho do partido foi ainda melhor no Nordeste, onde conseguiu eleger $24,7 \%$ do total de prefeitos, e nos segmentos IDH baixo e APU elevado, $24,7 \%$ e $24,4 \%$ dos prefeitos eleitos, respectivamente.

Em 2004, o resultado geral do partido declina na comparação com a eleição anterior. O percentual de prefeitos eleitos pelo PFL no total de municípios cai para $14,2 \%$, percentagem praticamente igual à obtida nos municípios com menos de 20 mil (14,8\%). Contudo, a discrepância entre esses resultados e a desempenho no Nordeste, nos municípios de IDH baixo e APU alto se acentuou. Nesses últimos três segmentos, o PFL conquistou 23,1\%,21,9\% e 20,3\% das prefeituras, respectivamente.

Em 2008, já como DEM, as características da performance do partido nas eleições municipais alteraram-se drasticamente. O primeiro ponto a destacar é a queda acentuada do total de prefeitos eleitos pelo partido, movimento que já se vislumbrava em 2004. A novidade é que essa queda ocorre principalmente nos segmentos onde, até então, o partido saia-se melhor, isto é, as cidades menores, localizadas no Nordeste, pouco desenvolvidas e muito dependentes do setor público. O desempenho do partido tornou-se praticamente uniforme. Deixou de haver diferença entre a sua participação no total de prefeitos eleitos e a verificada nos segmentos destacados. Isso pode ser mais bem visualizado na Tabela 6, a qual apresenta um índice que compara o desempenho relativo dos partidos no total de municípios e nas amostras selecionadas segundo os critérios já explicados. Esse índice foi obtido por meio da divisão do percentual representativo da participação dos partidos em cada um dos segmentos pelo percentual obtido no total das prefeituras. Assim, os números da coluna I da Tabela 6 foram obtidos por meio da divisão da coluna II pela coluna I da Tabela 5; os da coluna II da Tabela 6 são resultantes da divisão da coluna III pela coluna I da Tabela 5, e assim sucessivamente. Quanto mais próximos de 1 forem os números da Tabela 6, mais uniforme foi o desempenho do partido. Se o índice for maior do que 1 , significa que a legenda sai-se melhor nos municípios que qualificamos como de viés governista do que no conjunto geral. Ocorre o inverso quando o índice é menor do que 1. Neste caso, o desempenho do partido é relativamente melhor nos municípios não caracteristicamente governistas.

No caso do PFL, os índices quase sempre estão significativamente acima de 1 em 2000 e 2004 (a exceção ocorre no grupo de municípios com menos de 20 mil habitantes), mas praticamente igualam-se a $1 \mathrm{em} \mathrm{2008,} \mathrm{o} \mathrm{que} \mathrm{demonstra}$ que o partido, oito anos após ter se afastado do poder, enfraqueceu-se especialmente em sua tradicional base política, composta pelos municípios nordestinos, pouco desenvolvidos e dependentes do setor público. A queda de rendimento foi generalizada. Porém, foi mais aguda justamente onde o partido era, até então, mais forte.

Os números relativos aos demais partidos, embora indiquem que as categorias governista ou não governista explicam apenas parcialmente o desempenho das legendas nas eleições municipais, corroboram a ideia de que um partido 
Tabela 5 - Resultado das eleições municipais, geral e por segmentos

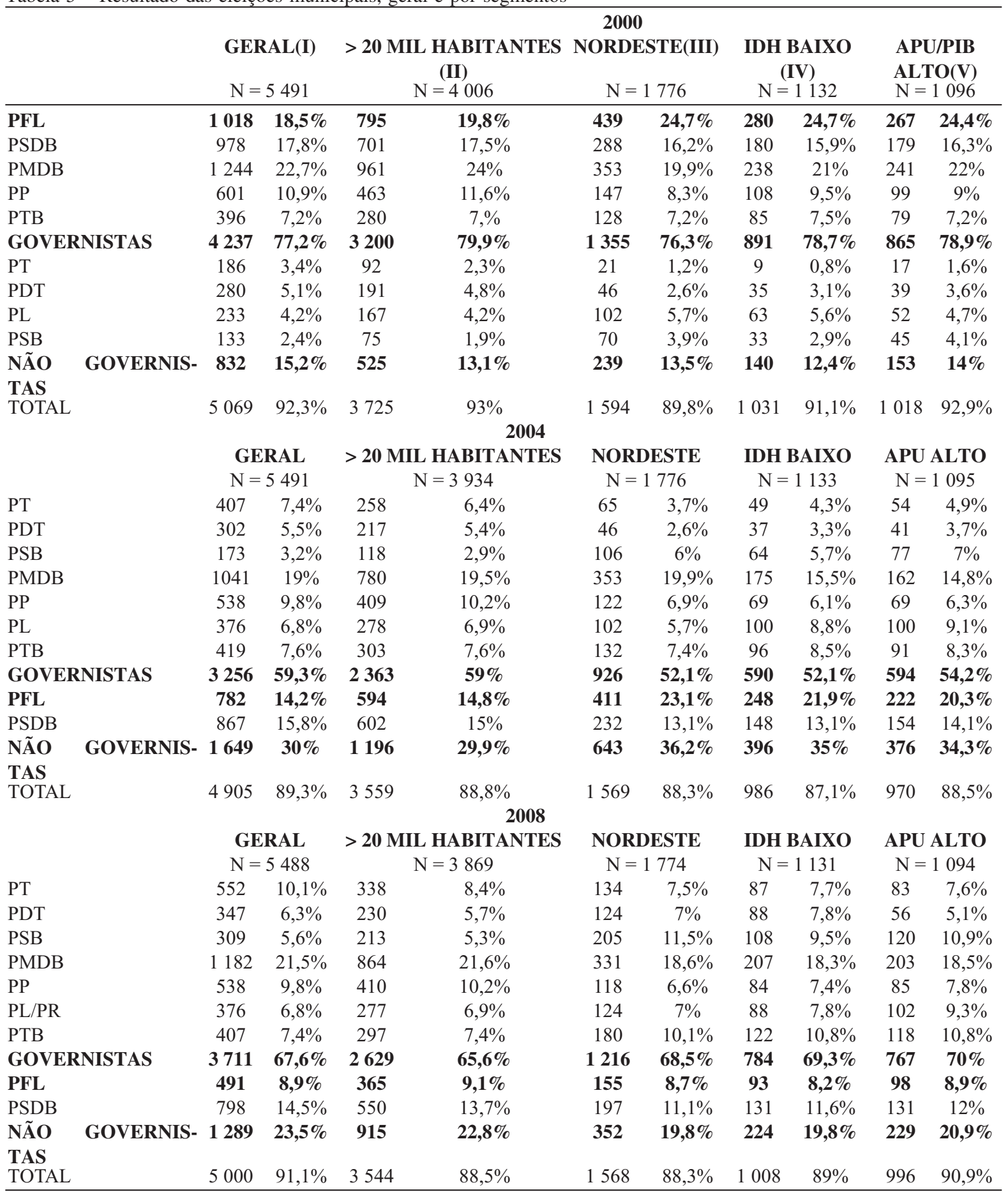

Fontes: Tribunal Superior Eleitoral; IBGE (2008).

tende sair-se melhor nos municípios de viés governista quando faz parte da coligação que sustenta o governo federal. Os casos do PSDB, PT e PSB subsidiam essa afirmação. 
Tabela 6 - Desempenho relativo dos partidos nas eleições municipais

$>20$ MIL HABITANTES(I) NORDESTE(II) IDH BAIXO(III) APU/PIB ALTO(IV)

\begin{tabular}{|c|c|c|c|c|}
\hline PFL & 1,07 & 1,33 & 1,33 & 1,31 \\
\hline PSDB & 0,98 & 0,91 & 0,89 & 0,92 \\
\hline PMDB & 1,06 & 0,88 & 0,93 & 0,97 \\
\hline PP & 1,06 & 0,76 & 0,87 & 0,83 \\
\hline PTB & 0,97 & 1 & 1,04 & 1,00 \\
\hline GOVERNISTAS & 1,04 & 0,99 & 1,02 & 1,02 \\
\hline PT & 0,68 & 0,35 & 0,23 & 0,46 \\
\hline PDT & 0,94 & 0,51 & 0,61 & 0,70 \\
\hline PL & 0,98 & 1,35 & 1,31 & 1,12 \\
\hline PSB & 0,77 & 1,63 & 1,20 & 1,70 \\
\hline \multirow[t]{3}{*}{ NÃO GOVERNISTAS } & 0,86 & $\mathbf{0 , 8 9}$ & 0,82 & 0,92 \\
\hline & 2004 & & & \\
\hline & > 20 MIL HABITANTES & NORDESTE & IDH BAIXO & APU ALTO \\
\hline PT & 0,87 & 0,49 & 0,58 & 0,66 \\
\hline PDT & 0,98 & 0,47 & 0,59 & 0,68 \\
\hline PSB & 0,93 & 1,89 & 1,79 & 2,23 \\
\hline PMDB & 1,03 & 1,05 & 0,82 & 0,78 \\
\hline PP & 1,04 & 0,70 & 0,62 & 0,64 \\
\hline PL & 1,01 & 0,84 & 1,29 & 1,33 \\
\hline PTB & 0,99 & 0,97 & 1,11 & 1,09 \\
\hline GOVERNISTAS & 0,99 & $\mathbf{0 , 8 8}$ & $\mathbf{0 , 8 8}$ & 0,91 \\
\hline PFL & 1,04 & 1,62 & 1,54 & 1,42 \\
\hline PSDB & 0,95 & 0,83 & 0,83 & 0,89 \\
\hline \multirow[t]{3}{*}{ NÃO GOVERNISTAS } & 0,99 & 1,21 & 1,16 & 1,14 \\
\hline & 2008 & & & \\
\hline & > 20 MIL HABITANTES & NORDESTE & IDH BAIXO & APU ALTO \\
\hline PT & 0,84 & 0,75 & 0,76 & 0,75 \\
\hline PDT & 0,91 & 1,10 & 1,23 & 0,81 \\
\hline PSB & 0,94 & 2,05 & 1,70 & 1,95 \\
\hline PMDB & 1 & 0,87 & 0,85 & 0,86 \\
\hline PP & 1,04 & 0,68 & 0,76 & 0,79 \\
\hline $\mathrm{PL} / \mathrm{PR}$ & 1,01 & 1,02 & 1,14 & 1,36 \\
\hline PTB & 1 & 1,37 & 1,45 & 1,45 \\
\hline GOVERNISTAS & 0,97 & 1,01 & 1,02 & 1,04 \\
\hline DEM & 1,02 & 0,98 & 0,92 & 1,00 \\
\hline PSDB & 0,94 & 0,76 & 0,80 & 0,82 \\
\hline NÃO GOVERNISTAS & 0,97 & 0,84 & 0,84 & $\mathbf{0 , 8 9}$ \\
\hline
\end{tabular}

Fontes: Tribunal Superior Eleitoral; IBGE (2008).

Quanto ao PSDB e ao PT, os números mostram que essas duas legendas, ao contrário do PFL, são relativamente mais fracas nos grupos de municípios selecionados (> 20 mil habitantes, Nordeste, IDH baixo e APU/PIB alto). Seus índices ficaram consistentemente abaixo de 1 independentemente de estarem ou não no poder nacional. Isto certamente é decorrência da gênese dos dois partidos, que nasceram e desenvolveram-se tendo como principal base a região Sudeste, principalmente o estado de São Paulo. Os índices são especialmente modestos para o PT, cujo desempenho é marcantemente ruim nos municípios que fazem parte dos segmentos destacados nas Tabelas 5 e 6.

Os números da Tabela 6 mostram, no entanto, que os índices do PT subiram nas eleições de 2004 e 2008 e se aproximaram de 1, enquanto os do PSDB caíram e tornaram-se ainda mais distantes de 1 . Ou seja, após o PT ter substituído o PSDB na Presidência da República, aumentou a força eleitoral do pe- 
tismo nos municípios menores, nordestinos, pouco desenvolvidos e dependentes do setor público, ao passo que o PSDB perdeu espaço nesses municípios, não tanto quanto o PFL, mas ainda assim de maneira significativa.

Observe-se agora o que aconteceu com o PSB. Os socialistas, assim como os pefelistas, sempre tiveram desempenho melhor nos municípios do Nordeste, de baixo IDH e alto APU/PIB. Seus índices sempre ficaram acima de 1. Porém, de 2000 para 2004 e 2008, ou seja, depois de o PSB ter chegado ao poder federal como um dos principais aliados do PT, quase todos os seus índices subiram e distanciaram-se ainda mais de 1. Isso significa que o PSB tornou-se ainda mais forte nos municípios que qualificamos como governistas.

Os índices do PT, do PSDB e, em especial, do PFL, mostram que a mudança no perfil do desempenho desses partidos nas eleições municipais acentuouse de 2004 para 2008. Isso indica que 2004 pode ter sido uma eleição de transição para a nova conformação política decorrente da chegada do PT ao poder. Essa eleição ocorreu apenas um ano e nove meses após a posse do presidente Lula na Presidência da República, tempo insuficiente para influenciar significativamente o balanço de poder na esfera municipal. Ademais, em 2004, o Bolsa Família, programa que seguramente deu grande impulso à popularidade de Lula e de seu governo nos municípios menos desenvolvidos e no Nordeste, dava ainda os seus primeiros passos. Como ilustraram as declarações de dirigentes do PFL presentes neste artigo, foi justamente a partir de 2004 que o PT e seus aliados começaram a avançar mais fortemente sobre a base eleitoral tradicional do partido.

O melhor desempenho relativo do PT - na verdade, mais de Lula do que do PT - junto ao eleitorado mais pobre manifestou-se com nitidez na eleição presidencial de 2006, como destacam Singer (2009) e Zucco (2008; 2010). Ambos concordam que o Bolsa Família e a política de aumento real do salário mínimo adotada por Lula - Singer destaca também o crédito consignado foram importantes para que o petista conquistasse apoio dos eleitores mais pobres. Mas Singer lança mão também de um argumento de cunho sociológico para explicar a ampliação do lulismo nas camadas de renda mais baixa. Segundo ele, a manutenção da ordem econômica e social durante o governo Lula foi fundamental para a adesão do que ele chama de "subproletariado" ao lulismo, pois este segmento seria avesso à crispação social. Já Zucco, no artigode 2010, destaca, como já vimos, a importância do viés governista existente nas regiões mais pobres do país. Apesar de considerar importante o efeito do Bolsa Família, para Zucco, o fato de Lula ter ido relativamente melhor nessa parcela do eleitorado em 2006 não é uma novidade. Foi, em parte, a mera repetição do "incumbency effect". O não usual, segundo Zucco, foi o desempenho de Lula entre os habitantes mais pobres das regiões mais desenvolvidas do país, para os quais haveria evidências de que historicamente apresentariam viés anti-governista. Embora diferentes, as explicações de Singer e Zucco não são antagônicas. Podem ser consideradas complementares. E ambos estão de acordo que, de 2002 para 2006, houve mudança da base de votação de Lula, que se tornou proporcionalmente maior nas áreas mais pobres do país e entre os eleitores de menor renda. Nas eleições locais, esse fenômeno parece ter se manifestado com força apenas em 2008, o que se pode visualizar a partir da análise dos índices do PT, PSDB e PFL apresentados na Tabela 6.

Por fim, para encerrar a análise descritiva dos dados, o recuo do PFL/DEM e do PSDB no Nordeste e o avanço concomitante e proporcional dos partidos que passaram a ser governistas a partir de 2003 (PT, PSB, PCdoB e PL/PR) 
são bastante visíveis na Tabela 7, que apresenta o total de prefeituras conquistadas por esses partidos nas últimas três eleições locais. Em 2008, quando parece ter ocorrido de maneira mais significativa o ajuste do poder político municipal à substituição do PSDB pelo PT na Presidência da República, o número de prefeituras perdidas por PSDB e PFL/DEM foi praticamente igual às conquistadas pelos novos governistas. Como pode-se ver na última coluna da Tabela 7, a diferença foi de apenas oito prefeituras. PT e PSB foram os que mais se beneficiaram do enfraquecimento de PFL/DEM e PSDB na região. Somados, esses dois partidos ganharam 249 prefeituras na região.

Testes de média para as variáveis população, IDH e APU/PIB também indicam que há diferença entre o desempenho dos partidos governistas e não governistas nesses segmentos. Os testes foram feitos para todos os partidos e, posteriormente, apenas para o PFL/DEM, quando este fazia parte da coligação governista e após ter ido para a oposição. A eleição de 2004 foi excluída da amostra, pois, como foi argumentado acima, parece ter sido uma eleição de transição. Os resultados estão na Tabela 8 , a seguir. Os testes mostraram de maneira estatisticamente consistente que, tanto para o conjunto dos partidos, como para o PFL: (i) a média da população dos partidos governistas é menor do que a dos não governistas; (ii) o IDH dos governistas é menor; (iii) a relação APU/PIB é maior para os governistas.

Serão apresentados agora os modelos estatísticos. A variável dependente é o desempenho dos partidos - medido pela eleição de seu candidato e não pela quantidade de votos obtidos pelo partido - nos pleitos 2000 e 2008. Pelas razões já explicadas, foram excluídos da amostra os dados da eleição de 2004. Como o objetivo é avaliar o efeito da mudança do status dos partidos - de governista para não governista e vice-versa -, foram excluídas também as prefeituras conquistadas pelo PMDB, PP e PTB pois a condição desses partidos não se alterou na transição do governo tucano para o petista. Eram e continuaram sendo partidos governistas. Assim, para fins dos modelos estatísticos aqui apresentados, apenas PSDB e PFL foram considerados governistas em 2000, enquanto PT, PSB, PDT e PL/PR são os não governistas. Já a partir de 2004, invertem-se essas condições: PT, PSB, PDT e PL/PR são governistas e PSDB e DEM passam a ser não governistas. Os partidos foram tratados como uma variável binária. Foi atribuído valor 1 para os governistas e 0 para os não governistas. As variáveis independentes do modelo são: $(i)$ a população do município; (ii) IDH municipal; (iii) relação APU/PIB e (iv) uma dummy de localização regional do município: 1 para os municípios nordestinos e 0 para os demais.

Tabela 7 - Prefeitos eleitos por partidos governistas e não governistas no Nordeste

\begin{tabular}{lcccccc}
\hline & $\mathbf{2 0 0 0}$ & $\mathbf{2 0 0 4}$ & $\mathbf{2 0 0 8}$ & $\mathbf{2 0 0 4 - 2 0 0 0}$ & $\mathbf{2 0 0 8 - 2 0 0 4}$ & $\mathbf{2 0 0 8 - 2 0 0 0}$ \\
\hline PFL/DEM & 439 & 411 & 154 & -28 & -257 & -285 \\
PSDB & 288 & 232 & 197 & $\mathbf{- 5 6}$ & -35 & -91 \\
TOTAL & $\mathbf{7 2 7}$ & $\mathbf{6 4 3}$ & $\mathbf{3 5 1}$ & $\mathbf{- 8 4}$ & $\mathbf{- 2 9 2}$ & $\mathbf{- 3 7 6}$ \\
PT & 21 & 65 & 134 & 44 & 69 & 113 \\
PSB & 70 & 107 & 206 & 37 & 99 & 136 \\
PDT & 46 & 54 & 124 & 8 & 70 & 78 \\
PCdoB & 1 & 7 & 36 & 6 & 29 & 35 \\
PL/PR & 102 & 142 & 124 & 40 & -18 & 22 \\
TOTAL & $\mathbf{2 4 0}$ & $\mathbf{3 7 5}$ & $\mathbf{6 2 4}$ & $\mathbf{1 3 5}$ & $\mathbf{2 4 9}$ & $\mathbf{3 8 4}$ \\
\hline
\end{tabular}

Fonte: Tribunal Superior Eleitoral. 
${ }^{23}$ Para análise sobre as aplicações e características deste tipo de modelo, ver Wooldridge (2003, p. 554-565).

${ }^{24}$ A respeito dos efeitos da multicolinearidade sobre regressões múltiplas, ver Wooldridge (idem, p. 97-100).
Tabela 8 - Testes de média, partidos governistas e não governistas

\begin{tabular}{|c|c|c|c|c|c|c|}
\hline & \multicolumn{2}{|c|}{ IDH } & \multicolumn{2}{|c|}{ População } & \multicolumn{2}{|c|}{ APU/PIB } \\
\hline & $\begin{array}{c}\text { Governis- } \\
\text { tas }\end{array}$ & $\begin{array}{c}\text { Nãogo- } \\
\text { vernistas }\end{array}$ & $\begin{array}{c}\text { Governis- } \\
\text { tas }\end{array}$ & $\begin{array}{c}\text { Nãogover- } \\
\text { nistas }\end{array}$ & $\begin{array}{c}\text { Governis- } \\
\text { tas }\end{array}$ & $\begin{array}{c}\text { Nãogover- } \\
\text { nistas }\end{array}$ \\
\hline $\begin{array}{l}\text { Todos os parti- } \\
\text { dos }\end{array}$ & $0,698 * *$ & $0,702 * *$ & $28562 *$ & $41101 *$ & $0,266^{*}$ & $0,260^{*}$ \\
\hline PFL/DEM & $0,677^{*}$ & $0,701^{*}$ & $23135 * * *$ & $45009 * * *$ & $0,292 *$ & $0,266^{*}$ \\
\hline
\end{tabular}

Notas: * Significativo a $1 \%$; ** Significativo a $5 \%$; ** Significativo a $10 \%$.

Os dados foram tratados por modelos estatísticos de tipo probit ${ }^{23}$. No primeiro deles estão presentes todas as variáveis. Nos modelos seguintes foram testadas apenas uma variável por vez, acompanhada da constante. Em todos os modelos, as variáveis apresentam coeficientes com os sinais esperados, com exceção da variável APU/PIB no Modelo 1. Os coeficientes indicam que há relação inversa entre o desempenho dos partidos governistas e (a) o tamanho da população dos municípios (Modelo 5) e (b) o valor do IDH (Modelos 1 e 2). Ou seja, quanto menor e menos desenvolvido for o município, maior a chance de um partido governista eleger o prefeito. Os coeficientes mostram que a relação é direta nos casos da dummy regional (Modelo 3) e do APU/PIB (Modelo 4). Isso significa que a chance de um partido governista eleger seu candidato a prefeito é maior nos municípios localizados no Nordeste e com elevada relação APU/PIB. São resultados coerentes com os números apresentados nas Tabelas 5 e 6 e também com os testes de média.

No modelo com todas as variáveis (Modelo 1), apenas o coeficiente da variável IDH foi estatisticamente significativa. Uma possível explicação para a insignificância estatística dos coeficientes das variáveis população, dummy regional e APU/PIB no Modelo 1 é a existência de multicolinearidade entre elas e entre essas e o IDH. Se há multicolinearidade, não se sustenta o pressuposto de independência entre as variáveis exógenas. Assim, embora conjuntamente, as variáveis expliquem o modelo, individualmente são estatisticamente insignificantes ${ }^{24}$.

A mais forte indicação de que há multicolinearidade entre essas variáveis é o fato de seus coeficientes, ao contrário do modelo completo (Modelo 1), terem se mostrado estatisticamente significativos quando cada uma delas foi tratada isoladamente (Modelos 3, 4 e 5). Outra indicação de que há multicolinearidade entre essas variáveis é que $89,2 \%$ dos municípios definidos como de IDH baixo (menor que 0,616) estão localizados no Nordeste e 76,3\% dos municípios de APU/PIB alto (maior que 0,403) também são nordestinos. Ou seja, a grande maioria dos municípios com tais características está no Nordeste. Os números das Tabelas 5 e 6 também mostram evidências de que há multicolinearidade pelo menos entre as variáveis Nordeste, IDH e APU/PIB. Nas tabelas, é possível verificar que os percentuais e os índices da maioria dos partidos são bastante semelhantes para o Nordeste, IDH baixo e APU/PIB alto. Por

Tabela 9 - Resultados modelos estatísticos

\begin{tabular}{|c|c|c|c|c|c|}
\hline & Modelo 1 & Modelo 2 & Modelo 3 & Modelo 4 & Modelo 5 \\
\hline Constante & $2,2129 *(0,3383)$ & $1,6250 *(0,1463)$ & $0,2485 *(0,0206)$ & $0,1503 *(0,0368)$ & $0,5912 *(0,1378)$ \\
\hline IDH & $-2,3377 *(0,4035)$ & $-1,8561 *(0,2079)$ & - & - & - \\
\hline $\begin{array}{l}\text { População(ln da popula- } \\
\text { ção) }\end{array}$ & $-0,0134(0,0156))$ & - & - & - & $-0,0278 *(0,0145)$ \\
\hline APU/PIB & $-0,5093(0,1984)$ & - & - & $0,6659 *(0,1226)$ & - \\
\hline Dummy regional & $0,0376(0,5592)$ & - & $0,2467 *(0,0364)$ & - & - \\
\hline
\end{tabular}

1. Valores em parênteses indicam o desvio padrão das variáveis.2. * Significativo a 1\%. 3. N= 5687. 
exemplo, os percentuais do PFL nesses segmentos foram, respectivamente, de $24,7 \%, 24,7 \%$ e $24,4 \%$ em $2000 ; 23,1 \%, 21,9 \%$ e $20,3 \%$ em 2004 ; e de $9,1 \%$, $8,7 \%$ e $8,2 \%$, em 2008 . Esse padrão de semelhança repete-se para a maioria dos demais partidos.

Feitas essas considerações a respeito da multicolinearidade, pode-se dizer que os resultados dos modelos estatísticos parecem bastante robustos, especialmente para o IDH. Estão também alinhados com os exercícios estatísticos realizados por Zucco (2010), os quais o levaram a concluir que o candidato presidencial incumbente, nas eleições de 1994 a 2010, sempre se saiu relativamente melhor nos municípios de menor IDH.

Sumarizando as conclusões que podem ser extraídas da analise descritiva dos dados apresentados nas Tabelas 5, 6 e 7, dos testes de média e dos modelos estatísticos, pode-se afirmar que: $(i)$ os partidos governistas têm melhor desempenho eleitoral nos municípios menos desenvolvidos (IDH baixo), economicamente mais dependentes do setor público (relação APU/PIB alta), localizados no Nordeste e menos populosos. As indicações são mais robustas para o IDH e menos para a população; (ii) consequentemente, pode-se inferir que certos municípios possuem viés governista; (iii) há evidências de que a eleição de 2004 foi de transição. O ajuste local à chegada do PT ao poder federal parece ter ocorrido de maneira mais significativa apenas em 2008; (iv) a transição do PFL para a oposição acarretou acentuado declínio do desempenho do partido nos municípios que parecem ter viés governista.

Tais conclusões reforçam a avaliação de que os dois movimentos que provocaram o enfraquecimento do partido - a saída de parlamentares e o mau desempenho eleitoral nas cidades de perfil governista - estavam interconectados e se retroalimentaram. Afinal, ambos ocorreram com mais intensidade no Nordeste, onde o PFL foi mais forte durante a sua fase governista.

\section{O desmonte do PFL na Bahia}

A ideia de que a passagem para a oposição acarretou o progressivo encolhimento do PFL é também corroborada por artigo de Borges (2010). No artigo, Borges propõe-se a explicar a vitória de coalizões de centro-esquerda na eleição de 2006 em estados até então dominados por grupos políticos quase oligárquicos de centro-direita. Isso ocorreu mais caracteristicamente na Bahia, no Maranhão e no Ceará.

Borges apresenta duas hipóteses para explicar o enfraquecimento dos antigos chefes políticos. A primeira está relacionada ao que ele chama de "competição vertical", ou seja, entre esferas de governo. Diz Borges (idem, p. 172) que "em sistema federais como o brasileiro, o governo central e os governos subnacionais competem por um mesmo pool de eleitores ao ofertar serviços similares ofertados pelo governo [...] Disso decorre que as estratégias de construção de máquinas políticas estaduais tendem a ser mais bem-sucedidas em contextos caracterizados pela coincidência, ao longo do tempo, ente os partidos e coalizões que ocupam os governos federal e estadual". A segunda hipótese diz respeito ao sistema eleitoral proporcional adotado no Brasil, que favoreceria a fragmentação partidária e dificultaria "a obtenção de maiorias eleitorais por um único partido o que obriga as elites estaduais [...] a envolverse em um processo complexo e extremamente custoso de negociação e barganha entre partidos" (ibidem). Assim, apesar do predomínio dos grupos oligár- 
${ }^{25}$ Por conta desse episódio, ACM teve de renunciar a seu mandato de senador em maio de 2001. Caso contrário, correria o risco de ser cassado. Mas logo voltou ao Senado, após vencer a eleição em 2002. quicos de centro-direita, subsistiria nos estados algum nível de competição eleitoral.

A segunda hipótese, embora correta, não é fundamental aos propósitos de Borges. Ela não explica porque houve a substituição de um grupo político por outro em 2006. Afinal, a fragmentação partidária já existia antes de 2006. O que mudou foi a conexão entre esses grupos políticos e o poder central, após a eleição de Luiz Inácio Lula da Silva. A perda do acesso ao poder central fragilizou os antigos grupos dominantes nos estados e deixou-os mais expostos à competição eleitoral. Do ponto de vista do poder local (prefeitos e lideranças políticas municipais), especialmente nos municípios menores e mais pobres, a aliança com esses grupos deixou de ser conveniente, porque eles não eram mais bons canais de distribuição de benefícios transferidos pelo governo federal às localidades. Passou a ser mais vantajosa a proximidade com forças políticas que ainda estavam na oposição nos estados (PT, PSB e demais aliados) mas que já pertenciam à coalizão governista na esfera federal.

A derrota de Paulo Souto (PFL) para Jacques Wagner (PT), na Bahia em 2006 serve a Borges como caso exemplar do processo acima descrito. A vitória de Wagner encerrou um longo período de predomínio do grupo de Antônio Carlos Magalhães na política baiana, o qual se estendeu de 1982 a 2006, interrompido apenas por quatro anos (1986-1990). Segundo Borges (idem, p. 177), "no plano estadual, ACM e seus aliados valeram-se da alocação estratégica de cargos e verbas [federais] para cooptar parcela importante da oposição de centro, ao mesmo tempo em que submetiam as prefeituras não alinhadas ao Executivo estadual a um verdadeiro 'bloqueio financeiro'. Ao final dos anos 90, a oposição havia sido praticamente dizimada: o grupo carlista detinha o suporte de quase $90 \%$ dos 417 prefeitos do estado e $75 \%$ dos deputados da Assembleia Legislativa".

A partir de 2006, esse quadro alterou-se radicalmente. "Nas eleições de 2006", avalia Borges, "os prefeitos aliados ao carlismo viram-se diante de uma candidatura de oposição eleitoralmente viável, que contava ainda com o apoio de um Presidente-candidato extremamente popular entre as camadas mais pobres da população" (idem, p. 182). O carlismo, por sua vez, estava dividido e a própria figura de Antônio Carlos Magalhães estava desgastada por conta do seu envolvimento na quebra do sigilo da votação da cassação do ex-senador Paulo Otávio ${ }^{25}$. Esses fatores ajudaram a impulsionar a candidatura de Jacques Wagner, mas, diz Borges, "é lícito inferir que o pragmatismo político das bases municipais carlistas empurrou-as na direção do adesismo à candidatura oposicionista na perspectiva de manter-se ao lado das (prováveis) forças vitoriosas nos pleitos nacional e estadual, e assim garantir recompensas futuras na forma de acesso a cargos e verbas fundamentais para sua sobrevivência política" (ibidem). O fato de muitos prefeitos terem deixado o PFL logo após a eleição de 2006 para filiarem-se a partidos aliados a Jacques Wagner, mas também ao governo Lula, reforça essa interpretação. "Ao longo de 2007, muitos dos partidos integrantes da coalizão legislativa do Governador Jacques Wagner ganharam adesões de prefeitos previamente filiados ao PFL, PP e PL" (idem, p. 183). O partido que mais beneficiou-se foi o PMDB, cuja bancada de prefeitos baianos saltou de 47, em 2006, para 120 em 2007. O PFL, em contrapartida, perdeu 56 prefeitos. Possuía 115 prefeitos em 2006; ficou com 59 em 2007.

A bem construída e bem documentada análise feita por Borges acerca da conexão entre o poder local e o poder nacional, intermediado pelo poder esta- 
dual, tomando como exemplo o caso da Bahia, vai ao encontro das conclusões deste trabalho. Borges provê um relato do processo sobre o qual se indicou apenas a resultante final, isto é, a perda do poder local para forças políticas mais próximas ao governo Lula. Mostrou-se que, após um período de transição, o poder local, de 2000 a 2008, adequou-se às mudanças ocorridas na política nacional, que passou a ser dominada pelo PT e seus aliados a partir de 2003. Apresentou-se evidências de que esse processo foi mais acentuado nas cidades menores, mais pobres e mais dependentes da economia do setor público, o que também é confirmado pelo trabalho de Borges.

\section{Conclusões}

O anúncio de que o PFL mudaria de nome foi recebido com indisfarçável enfado pela imprensa política nacional. O sentimento era justificado. Não era a primeira vez que se assistia, no Brasil, a um partido em crise tirar da manga a carta da mudança de nome, como se isso, em um passe de mágica, pudesse resolver as dificuldades da legenda. Tal estratégia foi especialmente usual na trajetória do atual PP, com quem o PFL partilha raiz histórica comum. São galhos da mesma árvore: a outrora poderosa Arena - que chegou a ser classificada na década de 1970, por seu então presidente, Francelino Pereira, como o "maior partido do Ocidente" - esteio político dos governos militares entre 1965 e 1979. Antes de ser PP, o partido foi PDS, PPR e PPB. Portanto, até pelo exemplo dado por seu primo próximo, digamos assim, era inevitável a sensação de déjà vu diante da notícia de que o PFL também trocaria de nome.

Além de tédio, o anúncio da troca de nome suscitou também um comentário frequente. Dizia-se amiúde que a operação seria apenas uma "jogada de marketing" dos dirigentes do partido que o estariam "repaginando" a fim de camuflar o seu pecado original - o apoio ao regime militar - e outras nódoas acumuladas ao longo de sua existência. De fato, um dos objetivos do chamado processo de refundação do PFL foi, sim, apagar sua ligação com a ditadura militar de 1964. Pretendia-se também dar ao partido uma nova imagem pois, como mostrou fartamente a pesquisa realizada pela MCI, a opinião da maioria da opinião pública a respeito do PFL era francamente negativa. Portanto, de certa maneira, foi realmente uma jogada de marketing. Mas essa é apenas a face mais evidente desse processo que, como tentou-se mostrar neste trabalho, apresenta contornos mais interessantes a serem explorados.

A chave para ir além da abordagem "apenas uma jogada de marketing" está no evento que levou os dirigentes pefelistas a empenharem-se no processo de refundação do partido: a eleição de Lula para a Presidência da República e a consequente chegada do PT ao poder federal. Foi um acontecimento marcante para o país e também decisivo para a trajetória do PFL, que, pela primeira vez em sua história, viu-se desabrigado do poder nacional. A hipótese central deste trabalho é justamente a ideia de que a passagem do PFL para a oposição foi o fator desencadeador do processo de refundação do partido, que culminou no surgimento do DEM, e também do declínio do partido nos anos que se seguiram.

Há, é preciso reconhecer, pelos menos três outras explicações possíveis para a queda do PFL/DEM.

A decisão de refundar e a trocar o nome da legenda pode ter sido um erro da cúpula do partido. A sigla PFL era bastante conhecida no Nordeste, onde o partido era mais forte. A troca de nome pode ter contribuído para o definha- 


\footnotetext{
26 “'A particular contribuição oferecida pelos partidos para o desenvolvimento e a legitimação da democracia moderna foi a combinação dessas duas funções [representação e capacidade de governar]. Isto é, as fundamentais funções relacionadas à representação e à governabilidade foram desenvolvidas no seio de uma organização - o partido. A mesma organização que governava a cidadania também lhes dava voz, e a mesma organização que dava vazão à representação também manobrava as instituições da organização política. Isso foi fundamental para a legitimação do governo representativo nos sistemas políticos democráticos".
}

mento à medida que privou o eleitor, particularmente o nordestino, de uma marca conhecida. Essa é uma hipótese plausível, porém impossível de se comprovar. Não é possível saber, por falta de exemplo contrafatual, se as perdas pefelistas teriam sido menores caso não tivesse havido a refundação e o surgimento do DEM.

Duas causas mais estruturais também podem ser aventadas. A primeira remete à teoria dos partidos, particularmente a uma discussão recente na literatura a respeito da perda da conexão representativa que caracterizaria a maioria dos partidos contemporâneos. Como dizem Katz e Mair (2009, p. 5): "The unique contribution parties offered to the development of modern democracy and the process of legitimizing democracy was that they combined these crucial two roles [representation and govern]. That is, the key representative and governing functions of the polity were developed within an organization - the party. The same organization that governed the citizenry also gave that citizenry voice, and the same organization that channeled representation also managed institutions of the polity. This was the key to the legitimation of representative government in democratic political systems" 26 .

$\mathrm{Na}$ democracia representativa atual, contudo, os partidos teriam perdido a capacidade de conectarem-se de maneira estável e profunda a segmentos ou grupos que lhes serviriam de base social e lhes dariam conteúdo programático. Essa era uma característica típica dos chamados partidos de massa (DUVERGER 1970), que foi estiolando-se à medida que esse tipo de organização partidária foi superada pelo partido catch-all (Kirckheimer, 1966) e, posteriormente, pelo partido cartel (Katz \& Mair 1995; 2009). A perda da função representativa, insinuam Katz e Mair (2009), colocaria em risco a própria sobrevivência dos partidos ou ao menos os privaria de condições necessárias para que continuem a desempenhar papel central na democracia representativa moderna.

O declínio do PFL/DEM, naturalmente, não é prova substancial a favor do argumento de Katz e Mair. Contudo, é possível ler a derrocado pefelista a partir da abordagem proposta por Katz e Mair. Enquanto fez parte de coalizões governistas na esfera federal, o PFL cumpriu bastante bem a sua função governativa. Quando passou à oposição, faltou-lhe, contudo, uma base a quem representar. A sua base tradicional não era, para recuperar um termo um pouco fora de moda, orgânica ao partido. Como dizem Mainwaring, Meneguello e Power (2000, p. 61), a falta de bases coerentes com o seu ideário político seria uma característica típica dos partidos conservadores brasileiros. Um dos objetivos do processo de refundação foi justamente buscar uma base mobilizada que desse sustentação a um partido de centro-direita. Mas essa meta não foi alcançada. Quando precisou estabelecer laços de fidelidade com um novo tipo de eleitor, faltou ao PFL/DEM canais de acesso e legitimidade. Incapaz de representar qualquer segmento relevante da sociedade e de restabelecer o acesso à máquina do governo federal, o partido se debilitou. Nesse sentido, tinha razão o ex-senador Marco Maciel quando apontava a necessidade de o partido constituir uma base e deixar de ser apenas um partido de quadros. Quando o partido passou para a oposição, essa necessidade tornou-se premente.

Por fim, o encolhimento do PFL também pode ser tomado como uma evidência do amadurecimento do sistema político partidário brasileiro, sob o ponto de vista da adequação programática e ideológica entre diferentes segmentos sociais do eleitorado e os partidos que, teoricamente, os representam, ou deveriam representar. Nesse sentido, o fortalecimento do PT e de seus aliados entre 
27 "Viés a favor do governo nas localidades mais pobres do país [...] ainda é uma regularidade empírica em busca de uma teoria".

${ }^{28}$ A descrição feita por Borges (2010), da adesão de prefeitos pefelistas aos partidos aliados ao campo petista, mostra que a análise feita por Victor Nunes Leal acerca do sistema político de dominação da arena política local pelo poder nacional, com a intermediação das forças políticas dominantes nos estados, ainda é bastante útil para entender tais relações na política brasileira. Surpreende que Borges não tenha os mais pobres seria o ajustamento natural a uma situação mais coerente do ponto de vista da representação dos interesses. Tal como ocorre nas democracias mais maduras, os eleitores de menor renda passariam a constituir a base dos partidos de centro-esquerda e os eleitores mais abonados formariam a base dos partidos de centro-direita. Conforme Lipset, "em praticamente todos os países economicamente desenvolvidos, os grupos de mais baixa renda votam principalmente nos partidos de esquerda, enquanto aqueles de renda mais alta votam principalmente nos partidos de direita" (Lipset apud Mainwaring, Meneguello \& Power 2000, p. 69).

Não há como rejeitar preliminarmente qualquer uma dessas três explicações alternativas. A priori, é plausível que tenham contribuído para o declínio do PFL/DEM. Contudo, primeiro, elas não desqualificam a interpretação defendida neste artigo; segundo, as evidências empíricas e fatuais apresentadas nas seções anteriores são, a meu ver, suficientes para sustentar a hipótese de que a ida para a oposição foi o elemento decisivo para o enfraquecimento pefelista. Mostrou-se que a passagem para a oposição provocou estragos profundos no PFL. O efeito mais imediato foi a perda de parlamentares eleitos pelo partido que, em sua grande maioria - muitos antes mesmo da posse - rumaram para legendas aliadas ao governo petista. A esse movimento inicial seguiu-se o progressivo encolhimento eleitoral do partido. Nos dois casos, a perda foi maior no Nordeste, região onde o PFL era mais forte, mas que também parece ser uma área especialmente sujeita à influência do governismo federal.

A partir dos dados das eleições para prefeito em 2000, 2004 e 2008, foram encontradas evidências de que as condições governista e não governista, definidas em função do grupo que ocupa o poder nacional, estão relacionadas a perfis diferentes de desempenho dos partidos nas disputas municipais. Os partidos governistas parecem sair-se relativamente melhores nos municípios de menor população, menos desenvolvidos, mais economicamente dependentes do setor público e localizados no Nordeste.

Para usar uma expressão empregada por Zucco, que, embora trabalhe com dados das eleições presidenciais, chegou a resultado empírico semelhante ao exposto neste texto, esse "pro-government bias in poor places in the country [...] remains an empirical regularity in search of a theory"27 (Zucco 2010, p. 3).

Não se tem a pretensão de preencher tal lacuna teórica neste artigo. Posso apenas fazer eco ao apelo feito por Zucco a favor de uma teoria que explique tal fenômeno e que esteja afinada com a situação contemporânea do país, visto que o patrimonialismo de Faoro (1958), o neopatrimonialismo e a cooptação política de Schwartzman (1982), e o coronelismo de Leal (1993), que poderiam ajudar na fundamentação teórica desse fenômeno, tratam de um Brasil bastante diverso do atual. Há necessidade, em especial, de um novo "Coronelismo, enxada e voto",28.

O próprio Zucco, apesar de demandar uma explicação teórica, arrisca, como ele mesmo diz, algumas conjecturas. Segundo ele, "one way to rationalize a geography-base mechanism is that voters, and poor voters in particular, are responding to the delivery of tangible benefits, either directly in the form of pensions, benefits, in kind transfer to voters, or indirectly as through support for local projects and programs" 29 (Zucco 2010, p. 20). Assim, a hipótese lançada por Zucco é que a ação do governo federal é o elemento que explica tais relações. O Bolsa Família seria o exemplo mais visível, mas "it is probably the case that other policies, formal or informal, were playing the same role in previous periods, though probably less efficiently" (ibidem). Assim, o fato de que 
feito qualquer referência a Nunes Leal.

29 "Uma forma de racionalizar esse mecanismo de raiz geográfica é assumir que os eleitores, em particular os mais pobres, respondem à oferta de benefícios tangíveis diretos, na forma de pensões, benefícios e demais transferências do gênero a eles direcionadas, ou indiretos, na forma de apoio a programas e projetos locais".

30 "Provavelmente, outros programas, formais ou informais, desempenharam o mesmo papel, embora de maneira menos eficiente" (ibidem). Portanto, o fato de que "tudo o mais constante, os candidatos incumbentes tenham melhor desempenho nas localidades mais pobres" é uma evidência de que estes possuem "mais facilidade para alcançar os eleitores nas localidades mais pobres ou, reciprocamente, de que a oposição tenha mais dificuldade de atingi-los. A explicação pode ser simplesmente que o governo local nas cidades mais pobres dependem do governo federal e estão dispostos a se alinharem com os incumbentes para ampliar o acesso a recursos".

${ }^{31}$ A ideia do "projeto PFL" me foi sugerida por Antônio Paim em entrevista concedida em fevereiro de 2010, a quem agradeço a contribuição. "all else equal, incumbent candidates perform better in poorer places" é uma evidência de que estes possuem "greater ease to reach voters in poorer places or, conversely, greater difficulties by the opposition to reach them, and the reason might simply be that local government in poor places depend on the Federal government, and are willing to align themselves with the incumbent to increase their access to resources" ${ }^{30}$ (idem, p. 22). É uma explicação que, admite Zucco, remete à velha teoria do clientelismo, e que é corroborada por declarações dos pefelistas colhidas nas entrevistas, como esta: "aproximar-se do governo [federal] é uma necessidade. Muitos municípios [do Nordeste] não conseguem sobreviver sem aderir ao poder" (José Carlos Aleluia, entrevista).

Essa discussão remete-nos também a uma questão recorrente na ciência política brasileira: a força e a importância do aparelho estatal no Brasil, tema de grande centralidade, por exemplo, nas obras de Faoro (1958), Schwartzman (1982) e Souza (1976). E mostra, por outro lado, que os dirigentes do PFL partiram de um diagnóstico correto a respeito do que ocorreria com o partido após sua passagem para a oposição. Sabiam que o partido minguaria justamente onde era mais forte, no Nordeste e nos chamados grotões. Daí o empenho em "refundar" o partido, movimento que, sob esse ponto de vista, não deve ser confundido com uma "simples jogada de marketing".

Contudo, cinco anos após o seu surgimento, o DEM definha em praça pública. O partido não conseguiu compensar a queda no seu reduto tradicional com a ascensão em outras regiões e a conquista de um novo tipo de eleitorado. Ficou, dessa maneira, ainda mais distante do objetivo enunciado por Jorge Bornhausen de fazer do PFL uma versão brasileira do PP espanhol ou do PSD português. Os dirigentes do partido não lograram levar adiante o que seria o grande "projeto do PFL" 31 : construir um partido liberal conservador e eleitoralmente competitivo no Brasil, capaz de representar segmentos da sociedade mais avessos ao ideário de esquerda ou de centro-esquerda e, a partir dessa base, ascender por suas próprias pernas ao poder nacional.

Não se pode dizer com certeza que tal projeto esteja definitivamente sepultado. Mas, em contrapartida, é possível asseverar que o processo de refundação fracassou de maneira retumbante. Quanto a isso não há dúvida. A marca simbólica mais ilustrativa desse fracasso foi a saída de Jorge Bornhausen do partido em maio de 2011, justamente o principal artífice e condutor do processo de refundação. Bornhausen anunciou que não se filiará a outro partido e que abandonou a política partidária. Porém, todo o seu grupo político, inclusive seu filho, o deputado federal Paulo Bornhausen, deixou o DEM para juntar-se ao PSD.

Se a saída de Bornhausen é a marca simbólica do fracasso da refundação do PFL, o surgimento do PSD, projeto político articulado por Gilberto Kassab, prefeito de São Paulo e, até o final de 2010, o demista de maior visibilidade no país, pode ser o empurrão que faltava para retirar o DEM do grupo de principais partidos do país. O PSD atraiu 19 deputados federais do DEM, praticamente metade da bancada eleita em 2010, uma senadora (Kátia Abreu - TO), um dos dois governadores demistas (Raimundo Colombo - SC), um vice-governador (Guilherme Afif Domingos - SP) e dezenas de deputados estaduais, prefeitos e vereadores.

Desavenças internas entre o grupo político de Kassab, apoiado por Jorge Bornhausen, e dos Maia (Rodrigo e César) contribuíram para o racha. Mas a dificuldade de sobrevivência do partido na oposição parece ter sido o fator preponderante. 
${ }^{32}$ Frase de editorial do jornal O Estado de S. Paulo, 12 de outubro de 1963, citada em Souza (1976, p. 145-146).
Uma das explicações para o sucesso da criação do PSD, que nasceu como o terceiro partido de maior bancada na Câmara dos Deputados, é justamente o manifesto viés governista do partido. Como escreveu Gilberto Kassab em artigo no jornal Folha de São Paulo (Lima \& Magalhães 2011), "o PSD não fará oposição pela oposição" e nasce para "buscar consensos" e para "somar esforços para construir o bem comum". Segundo depreende-se das declarações de futuros pessedistas à imprensa e de notícias sobre o partido, a repulsa à "oposição pela oposição" e a busca de consensos e do "bem comum" não se limitará à esfera federal. Deverá estender-se também aos estados. Assim, o PSD, provavelmente, além de apoiar o governo Dilma Rousseff, será aliado do PSDB, em Minas Gerais, no Paraná e em São Paulo; do PT na Bahia; do PMDB no Rio de Janeiro e no Maranhão; do PSB em Pernambuco e no Ceará, e assim por diante. Ou seja, tal como o seu homônimo do período 1945-1964, o atual PSD pretende ser uma "ostra incrustada no casco da nau do Estado"32. A fórmula para a criação do partido complementa-se com a dispensa de qualquer veleidade ideológica. O PSD, anunciou Kassab à imprensa no final de março de 2011, "não será de direita, não será de esquerda, nem de centro".

É interessante notar que a criação do PSD representa o fecho do ciclo de decadência do PFL/DEM, que começou e pode terminar da mesma maneira: com a saída expressiva de políticos na direção de uma legenda de perfil mais governista. Conforme avaliação do governador pernambucano Eduardo Campos sobre o PSD, em entrevista ao jornal Valor, em 13 de maio de 2011, "o conjunto de forças que sempre esteve no governo, ao cabo de oito anos fora dele, resolveu mudar para ser o que sempre foi: base do governo". Enfim, fechou-se um ciclo. Esse ponto, ressaltado pela frase de Eduardo Campos, é relevante. Mostra a força do governismo no Brasil.

Ricardo Luiz Mendes Ribeiro (ricardomribeiro@uol.com.br) é Doutorando em Ciência Política na Universidade de São Paulo (USP).

\section{Referências bibliográficas}

Almeida, L.C., 2004. PPB: origem e trajetória de um partido de direita no Brasil. São Paulo. Dissertação de Mestrado. São Paulo: Universidade de São Paulo.

Ames, B., 1995. Electoral Strategy under Open-List Proportional Representation. American Journal of Political Science, 39 (2), pp. 406-433.

Benevides, M.V., 1981. A UDN e o Udenismo (ambiguidades do liberalismo brasileiro). Rio de Janeiro: Paz e Terra.

Campos, R.R., 2002. A face de um partido: base política e comportamento eleitoral do PFL Pernambuco, 1985-2001. Tese de Doutorado. São Paulo: Universidade de São Paulo.

Cantanhêde, E., 2001. O PFL. São Paulo: Publifolha.

Cardoso, F.H., 1975. Partidos e deputados em São Paulo. O voto e a representação política. In F.H. Cardoso \& B. Lamounier, eds. Os partidos e as eleições no Brasil. Rio de Janeiro: Paz e Terra.

Corbellini, J., 2005. O poder como vocação: o PFL na Política Brasileira (1984-2002). Tese de Doutorado. Porto Alegre: Universidade Federal do Rio Grande do Sul.

Dimenstein, G.; Fernandes, R.; Lopes, R.; Negreiro, J. \& Noblat, R., 1985. O complô que elegeu Tancredo.Rio de Janeiro: JB.

Duverger, M., 1970. Os partidos políticos. Rio de Janeiro: J. Zahar.

Faoro, R., 1958. Os donos do poder: formação do patronato político brasileiro. Rio de Janeiro: Globo.

Frias Filho, O., 1995. PFL 2000. Folha de S. Paulo, 8.jun.

Freitas, A., 2008. Migração partidária na Câmara dos Deputados. Dissertação de Mestrado. São Paulo: Universidade de São Paulo.

Hipólito, L., 1985. PSD, de raposas e reformistas. São Paulo: Paz e Terra.

Katz, R. \& Mair, P., 1993. The Evolution of Party Organizations in Europe: The three faces of party organization. InW. Crotty, ed. Political Parties in a Changing Age. Conway: University of Central Arkansas. [Edição especial da American Review of Politics, 14.] 
1995. Changing Models of Party Organization and Party Democracy: The emergence of the Cartel Party. Party Politics, 1(1), pp. 5-28.

1996. Cadre, Catch-All or Cartel? A Rejoinder. Party Politics,2(4), pp. 525-534.

1997. Party Organization, Party Democracy and the Emergence of the Cartel Party. In P. Mair, ed. Party Systems Change: Aproaches and interpretations. Oxford: Oxford University.

2009. The Cartel Party Thesis: A Restatement. Perspectives on Politics, 7(4), pp. 753-766.

Kinzo, M.D., 2005. Os partidos no eleitorado: percepções públicas e laços partidários no Brasil. Revista Brasileira de Ciências Sociais, 20(57), pp. 65-81.

Lamounier, B., 2005. Da Independência a Lula: dois séculos de política brasileira. São Paulo: Augurium.

Lavareda, A., 1985. O Partido da Frente Liberal: o dissenso dos governadores pedessistas nordestinos e a busca de uma nova imagem. In R. Falcão \& C.P. Sá, eds. Nordeste: eleições. Recife: Massangana.

Leal, P.R.F., 2005. O PT e o dilema da representação política: os deputados federais são representantes de quem? Rio de Janeiro: FGV.

Leal, V.N., 1993. Coronelismo, enxada e voto. São Paulo: Alfa-Ômega.

Lima, D. \& Magalhães, V., 2011. Kassab diz que PSD fará 'oposição responsável' a Dilma. Folha de S. Paulo, "Poder", 21.mar. Disponível em: http://www1.folha.uol.com.br/poder/891779-kassab-diz-que-psd-fara-oposicao-responsavel-adilma.shtml. Acesso em: 2.fev.2014.

Linz, J.J., 2002. Parties in Contemporary Democracies: Problems and Paradoxes. In R. Gunther; J.J. Linz \& J.R. Montero. Political Parties: Old concepts and new challenges. Oxford: Oxford University.

Lippi, L., 1973. O Partido Social Democrático. Dissertação de Mestrado. Rio de Janeiro: Instituto Universitário de Pesquisas do Rio de Janeiro.

Mainwaring, S., 1999. Sistemas partidários em novas democracias: o caso do Brasil. Rio de Janeiro: FGV.

Mainwaring, S.; Meneguello, R. \& Power, T., 2000. Partidos conservadores no Brasil contemporâneo. Rio de Janeiro: Paz e Terra.

Mair, P., 2009. Representative versus Responsible Government. MPIfG Working Paper 09/08.

Melo, C.R., 2004. Retirando as cadeiras do lugar: migração partidária na Câmara dos Deputados (1985/2002). Belo Horizonte: UFMG.

Nicolau, J., 2010. Dados eleitorais do Brasil (1986-2006).Sítio de internet. O endereço não estava mais disponível na data de publicação.

Power, T. J., 2000. The Political Right in Postauthoritarian Brazil - Elites, Institutions, and Democratization. University Park: Pennsylvania State University.

Ribeiro, R.L.M., 2011. Decadência longe do poder. Refundação e crise do PFL. Dissertação de Mestrado. São Paulo: Universidade de São Paulo.

Roma, C., 2002. A institucionalização do PSDB entre 1988 e 1999. Revista Brasileira de Ciências Sociais, 17(49), pp. 71-92.

Sampaio, R., 1982. Ademar de Barros e o PSP. São Paulo: Global.

Schwartzman, S., 1982. Bases do autoritarismo brasileiro. Rio de Janeiro: Campus.

Singer, A., 2010. Raízes sociais e ideológicas do Lulismo. Novos Estudos, 85,pp. 83-102.

Souza, M.C.C., 1976. Estados e partidos políticos no Brasil. São Paulo: Alfa-Ômega.

Strom, K., 1990. Minority Government and Majority Rule. Cambridge (UK): Cambridge University.

Tarouco, G.S., 1999. O Partido da Frente Liberal: Trajetória e papel no sistema político. Dissertação de Mestrado. Campinas: Universidade Estadual de Campinas.

2002. Fatores do desenvolvimento do Partido da Frente Liberal. In C.R.J. Pinto \& A.M. Santos, eds. Partidos no Cone Sul: novos ângulos de pesquisa. V. 1. Rio de Janeiro: Konrad-Adenauer-Stiftung.

Wolinetz, S. B., 2002. Beyond the Catch-All Party: Approaches to the study of parties and party organization in contemporary democracies. In R. Gunther; J.R. Montero \& J.J. Linz, eds. Political Parties: Old concepts and new challenges. Oxford: Oxford University.

Wooldridge, J.M., 2003. Introdutory Econometrics: A modern approach. Stamford (CT): Cengage Learning.

Zucco, C., 2008. The President's 'New' Constituency: Lula and the pragmatic vote in Brazil's 2006 presidential elections. Journal of Latin American Studies, 40(1), pp. 29-49.

2010. Poor Voters vs. Poor Places: Persisting patterns in presidential elections in Brazil. Disponível em:

http://www.fgv.br/professor/cesar.zucco/files/UNPUBpoorplaces.pdf. Acesso em: 2.fev.2014.

\section{Outras fontes}

Duas décadas depois, PFL anuncia 'refundação'. Folha de S. Paulo, 16.jan. Disponível em: http://acervo.folha.com.br/fsp/ 2005/01/16/2/. Acesso em: 16.fev.2014.

IBGE. 2008. PIB dos municípios. Disponível em:

www.ibge.gov.br/home/estatistica/economia/pibmunicipios/2004_2008/comentarios.pdf. Acesso em: 2.fev.2014.

MCI. 2004. PFL: imagem e reposicionamento. Mimeo. 
PFL. 2007. Refundação do Partido da Frente Liberal. Mimeo.

\section{Apêndice}

Relação de entrevistas

Jorge Bornhausen, ex-senador e ex-presidente do PFL. A entrevista foi realizada no dia 14 de maio de 2009, em São Paulo.

Marco Maciel, ex-vice-presidente da República e ex-senador pelo PFL/DEM. A entrevista foi realizada em 17 de novembro de 2009, em Brasília.

Saulo Queiroz, ex-deputado federal, ex-secretário geral e ex-tesoureiro do PFL/DEM. Entrevista realizada em 17 de novembro de 2009, em Brasília.

José Agripino Maia, senador pelo PFL/DEM. Entrevista realizada em 18 de novembro de 2009, em Brasília.

José Carlos Aleluia, ex-deputado federal pelo PFL/DEM. Entrevista realizada em 18 de novembro de 2009, em Brasília.

Gustavo Krause, ex-deputado e ex-ministro (governos Itamar Franco e Fernando Henrique Cardoso) pelo PFL. Entrevista realizada em 11 de dezembro de 2009, em Recife.

Antônio Lavareda, cientista político. Foi o principal responsável pela pesquisa da MCIsobre a imagem e o reposicionamento do PFL. Entrevista realizada em 11 de dezembro de 2009, em Recife.

Antonio Paim, cientista político. Foi durante vários anos assessor político do PFL/DEM. Entrevista realizada em 16 de março de 2010, em São Paulo.

\section{ABSTRACT}

This dissertation aims to analyze the re-foundation process of the Partido da Frente Liberal (PFL), which resulted in the change of command of the party and the replacement of the previous name of the legend by Democrats (DEM) in March 2007. We assume the hypothesis that the transfer of the PFL for the opposition since 2003, unprecedented in the history of the party, was the crucial event to the decision of party leaders to try to give new image and identity to the PFL. We argue also that the re-foundation aimed to reposition the PFL in Brazilian electoral political market in order to attract the support of the urban voters located in large and medium-sized cities. Interviews with political leaders and party, plus documents, promotional material and public opinion polls produced by PFL/DEM were used for the analysis and description of the PFL re-foundation process. Data about party switching phenomenon and PFL electoral performance before and after the path to the opposition to Lula administration were also employed. We show that the transition to the opposition led to the weakening of the PFL. Two movements together caused the retreat of the party: 1) the transfer of PFL politicians to parties allied to Lula's administration, 2) the poor electoral performance in the Northeast, traditional stronghold of the PFL during the time it was in the government and that was progressively dominated by parties which supported PT administration. Finally, dealing with the results of municipal elections in 2000, 2004 and 2008, we present data and statistical tests that support the idea that less developed municipalities, few populated, located in the Northeast region and whose economies are more dependent on public sector have a pro-government bias. That is, in these locations, more than in the rest of the country, local government tends to align with the federal government. This trend seems to provide a good explanation for the withdrawal of the PFL in municipalities with the characteristics specified above. The results presented here indicate the centrality of federal power in the Brazilian political system and the difficulty of survival faced by opposition party especially when it does not control important state governments, as was the case of PFL from 2006.

KEYWORDS: Political party; Party system; PFL; Local elections; Federal government power 